\title{
Experimental archaeology and roundhouse excavated signatures: the investigation of two reconstructed Iron Age buildings at Castell Henllys, Wales
}

\author{
Harold Mytum ${ }^{1}$ (D) James Meek ${ }^{2}$
}

Received: 11 July 2019 / Accepted: 7 February 2020 / Published online: 29 February 2020

(C) The Author(s) 2020

\begin{abstract}
Castell Henllys, a partially reconstructed Iron Age settlement in south-west Wales, has been the site of long-term experiments in building reconstruction for 35 years. The first roundhouse to be excavated and then reconstructed on the site was due to be replaced in 2017, and another reconstructed 30 years ago was examined in 2018. The results indicate how timber structures with wattle walls decay over a period of decades, and the evidence can be compared to that retrieved from the original excavated late prehistoric structures on the site and those found elsewhere. The pattern of wear of floors and surfaces, and the effects of decades of fires within the roundhouses, also produced archaeological signatures that can be compared with prehistoric remains. These investigations reveal for the first time how long-term processes of experimental house use, maintenance and decay in a temperate environment create archaeological signatures very similar to those found from prehistory, indicating how ancient deposits could have been formed. It also demonstrates how even roundhouses with relatively ephemeral below-ground elements can stand for at least a human generation.
\end{abstract}

Keywords Experiment $\cdot$ Reconstruction $\cdot$ Roundhouse $\cdot$ Iron Age $\cdot$ Excavation

\section{Introduction}

Later prehistoric settlements are frequently excavated in Britain, and many reveal structural evidence of buildings, mainly in the form of features such as postholes and wall foundations cut into the subsoil. In a small number of cases where subsequent land use has not destroyed prehistoric living surfaces, internal floors may be found. Late prehistoric domestic structures in Britain are normally circular in plan, though the nature of the subsurface evidence varies considerably, indicating a range of constructional methods (Cunliffe 1978; Harding 2009). Whilst the two-dimensional plans of typical Iron Age house types are now well known (Guilbert 1981), most inferences regarding the construction and

Harold Mytum

hmytum@liverpool.ac.uk

1 Department of Archaeology, Classics and Egyptology, University of Liverpool, Liverpool L69 7WZ, UK

2 Dyfed Archaeological Trust, Corner House, 6 Carmarthen Street, Llandeilo, Carmarthenshire SA19 6AF, UK appearance of roundhouses are dependent on logical deduction from the subsurface features.

The reconstruction of Iron Age roundhouses has been undertaken at a variety of locations within Britain (Fig. 1), within a tradition of reconstruction as experiment or public interpretation (Planel and Stone 1999; Reynolds 1999; Bell 2009; Millson 2011; Crothers 2016; Hurcombe and Cunningham 2016). However, many of these reconstructions are based on a generalised model of one of the commonly found house plans, not the detailed evidence from a specific excavation (Bell 2014). Those based on specific excavated examples were those reconstructed by Reynolds at Butser (Reynolds 1979) and roundhouses based on selected evidence from Moel y Gaer, Moel y Gerddi and Conderton that were displayed together at St Fagans National History Museum (Burrow 2015). These have, to varying degrees, considered and replicated the details from the original excavations but have been reconstructed at different locations which may or may not offer similar subsurface and micro-climatic conditions to the original exemplars. Of the roundhouse reconstructions that have been based on specific archaeological evidence, most have not received any academic publication. The exceptions are the details of the original reconstruction 


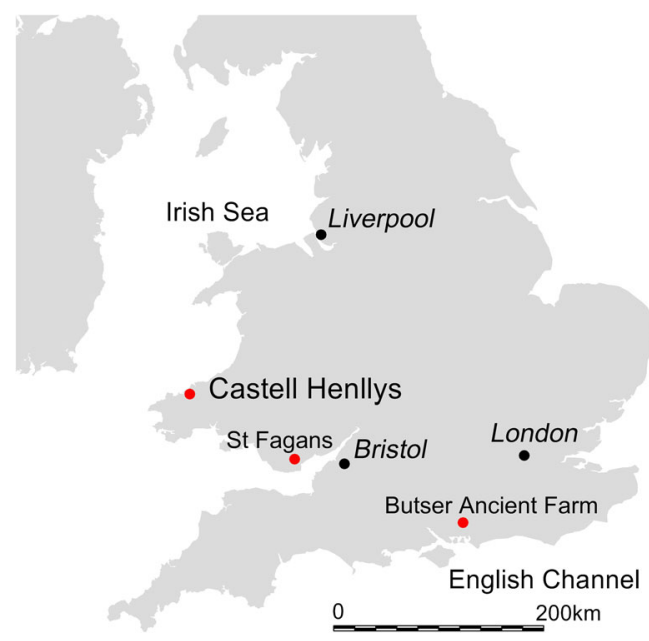

Fig. 1 Location of Castell Henllys and other reconstruction locations discussed

of the Castell Henllys roundhouse under discussion in this paper (Mytum 1986) and the Pimperne house that was built at Butser (Harding et al. 1993), though it was only allowed to stand for 13 years before being demolished when the lease of the experimental site was terminated (Harding 2009:208); the St Fagans Museum buildings stood for up to 20 years.

More recent reconstructions have been limited in their experimental value because health and safety considerations have meant that unauthentic features have been incorporated to allow public access, often essential at such sites for their public interpretation functions; this has been the case with one of the other roundhouses at Castell Henllys (Bennett 2010), and to a certain extent the replacement of the house discussed here (see below), and also the recent reconstructions at $\mathrm{St}$ Fagans museum (Burrow 2015) where the detailed structural archaeology from the Bryn Eryr farmstead, Anglesey (Longley 1998) forms the basis of the plan, but many structural details have had to be adapted for present-day museum conditions. These limitations were not in place when the Castell Henllys reconstructions took place in 1982 and 1986, although the buildings did have to pass planning regulations. Concerns regarding the stability of the building, and public safety, did lead to structural interventions on both roundhouses during the National Park period of management; these modifications and their archaeological signatures are discussed below.

Excavation of reconstructed roundhouse sites after they have been dismantled has been rare, and only two are briefly published (Reynolds 1982, 1994, 1995; Bell 2014). Reynolds attempted a number of reconstructions in the 1970s that were more or less successful in structural terms, but some consideration was given to the below-ground signatures that his experiments left behind. The geology on which the reconstructions took place was chalk, and the longest standing roundhouse was 15 years, so the results have to be considered within these constraints, but some significant data was recovered. The more recent example of excavation is from the St Fagans museum roundhouse that preceded the current Bryn Eryr farmstead mentioned above. Based on the excavated evidence at Moel y Gaer, this roundhouse stood for 21 years. The site was examined by Bell (2014) who noted a number of key findings, which are largely compatible with those of Reynolds, but add the dimensions of taphonomic processes by insects and the distribution of artefacts within the roundhouses. One of the other St Fagans reconstructions, the Moel y Geddi house, was excavated in 2012 (Burrow 2015) but is not yet published. Results from investigating deposits associated with roundhouse reconstructions have considered soils and pollen (Macphail et al. 2004; Carey et al. 2014; Banerjea et al. 2015), but this paper concentrates on the structural evidence and its implications.

The key findings of the Reynolds and Bell analyses helped to frame the hypotheses that were posed by the Castell Henllys excavations and data analysis in 2017 and 2018. However, as the Castell Henllys roundhouse reconstructions were exactly on the locations of the original structures and experienced the same topography and exposure to the elements as the originals in terms of wind direction and strength, rainfall and water runoff, these provide more accurately site-specific analyses from use-lives of three decades which can be compared and combined with those from previous investigations of shorter-lived roundhouses elsewhere.

\section{Site context}

The inland promontory of Castell Henllys was home to a community from the fifth to the first or second century BC. The promontory consists of a bedrock of Ordovician shales, with occasional bands of quartz, overlain by mixed glacial sediments of pink clay and orange and yellow gravels (Davies et al. 2004). The sides of the promontory on the east, south and west are very steep, with a gentle approach from the north; the spine of the promontory gently slopes to the east, south and west and was a factor in the design and construction of buildings within the fort.

The site was defined not only by the topography but also first by a timber palisade fence and then an arrangement of banks and ditches augmented by steepening of parts of the slopes of the promontory. This form of settlement was commonly occupied in south-west Wales at that time, but today, the site is unique as it has been very extensively excavated and indeed partially reconstructed under the site ownership and management of Hugh Foster (Mytum 2013). It is open to the public and, since 1992 when taken over by the Pembrokeshire Coast National Park, has supported an extensive schools programme (Mytum 2000) and utilized the reconstructions within a developed interpretive programme (Mytum 1999, 2004, 
2012). The reconstructions also offer the opportunity for longterm experimental archaeology research.

The owner of the site when excavations began in 1981, Hugh Foster, had the vision of reconstructing an Iron Age settlement and making it accessible to the public. The first author was asked to direct excavations with one of the specific remits being to uncover a complete Iron Age roundhouse plan so that a programme of reconstruction on the exact site of the original could be planned. Trial excavations at Easter were followed by a larger programme in the summer led to the excavation of the foundations of a roundhouse in the southeastern portion of the interior. This part of the site was chosen because there was limited stratigraphy, but the structural features such as postholes and wall gullies survived. As this roundhouse was reconstructed in 1982 (Mytum 1986), subsequent excavation seasons revealed further building foundations across the site. This roundhouse, first named the Prince William and later the Cookhouse roundhouse, was dismantled and excavated in 2017 , and its subsequent reconstruction completed in 2018.

A second, smaller roundhouse of $6 \mathrm{~m}$ diameter was excavated in 1983 and reconstructed in 1985, and it is now called the Smith's house and is still standing, and in 1986, another roundhouse was excavated to be reconstructed in 1988, immediately to the north of the first reconstruction and called the Earthwatch roundhouse. This reconstruction stood until 2018 when it was dismantled and excavated, and it is being replaced with a new version in 2019. A four-post structure with a raised floor and conical roof-a building often referred to as granaries in the archaeological literature, was reconstructed using the original postholes in 1989 and is still standing though has had some timber replacement. A final roundhouse, the Chieftain's house, is located approximately where the largest structure was excavated and has been built to dimensions not quite commensurate with the evidence. It uses engineering principles which have created a building conforming to modern building regulations and thus not reflecting prehistoric decision-making in a number of key respects; it was erected in 1999 in the north-eastern portion of the fort interior (Bennett 2004, 2010); this was the only structure where neither author had any influence over the design, and it can only be considered as a form of simulation. It is this structure that formed the central example in the critique of reconstruction provided by Townend $(2002,2007)$, who seems unaware of the variety of assumptions and decision making processes involved in reconstructions not only at Castell Henllys but also at other sites.

Other critiques of Castell Henllys as a heritage site have varied in their emphasis, but in no case are they addressing the experimental logics of the reconstructions themselves, but rather the wider contextualisation involving the Celts, Welsh nationalism and the challenges of presenting reconstructions as didactic experiments rather than statements of fact (Gruffudd et al. 1998, 1999; Piccini 1999; Collings 2007;
Mytum 2013; Woltz 2010). Of the four roundhouses and one four-post structure standing at Castell Henllys (Fig. 2), only the two reconstructed roundhouses that have been subsequently dismantled and re-excavated are discussed here as only they provide an experimental biography from original excavation, through reconstruction, use, dismantlement and re-excavation on a timescale that is of unique value for understanding the parameters of late prehistoric building construction, given that both structures stood for at least three decades.

\section{Cookhouse roundhouse excavation and reconstruction}

The original excavation of the Iron Age remains revealed a series of buildings, all successively rebuilt on almost exactly the same location, with concentric gullies and arcs of features representing the rebuilt timber houses. Some were constructed using posts set in a shallow gully, in other cases arcs of individual small postholes. The almost complete plan survived for one of these structural phases, and this was chosen for the basis of the reconstruction (Mytum 1986). The northern, uphill arc of the wall foundation aligned with two substantial postholes which represented the door posts, indicating a circular structure $10 \mathrm{~m}$ in diameter. In the centre was an oval hollow, presumed to be the site of the hearth, and most of the postholes of a concentric circle of inner posts lay between the hearth and the wall; two were missing because of animal disturbance of the subsoil, which varied from firm pink clay to soft pale yellow gravel. Outside the wall on the north and west was a gully, interpreted as an eaves-drip to carry rainwater away from the walls of the building. This form of roundhouse, common across Britain and known as the double-ring form (Guilbert 1981, 1982), would be the first to be reconstructed at Castell Henllys, though subsequent excavation indicated that this was the only roundhouse of this double ring form within the late prehistoric settlement.

There are three main challenges with building reconstruction: the first is moving from the two-dimensional to the three-

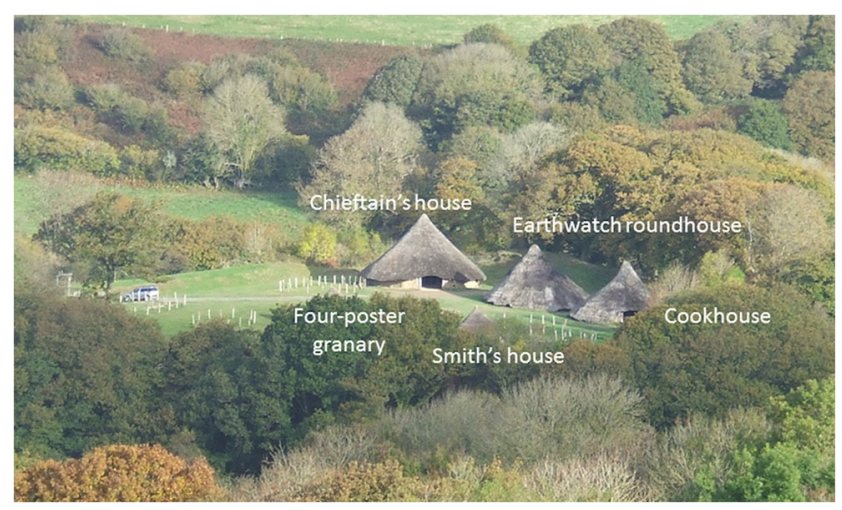

Fig. 2 Reconstructed buildings at Castell Henllys 
dimensional regarding structure and materials, the second is how to treat and finish the structural elements and the roof and the third is how to use the space within and what fittings and portable material culture should be present. Only the first of these is discussed here, as this is the focus of the report linking the experimental evidence of excavation of the reconstruction with that of the original excavation and that of other Iron Age roundhouses. The other challenges are more significant with regard to heritage interpretation (Mytum 2003, 2004) and how they affect public perception of the past, though the third does have some impact on how space may be used within the structure during its life and what types of finds may become incorporated within the building.

The simplest way to reconstruct the roundhouse was demonstrated by Reynolds at Butser, with the wall forming a cylinder with a horizontal top to the wall, and a cone-shaped roof placed on top of this (Reynolds 1979, 1982). In the case of a double-ring roundhouse, the inner ring of posts provided additional support for the roof. The eaves-drip gully represented the extent of the roof overhang away from the wall. From the position of wall and eaves drip gully, it was possible to infer a wall height and roof angle that ensured that the various components made sense as a structural whole (Mytum 1986). This provides the basic structural skeleton of the reconstruction and might be considered as a confident modelling based on the archaeological evidence. How the basic structure is implemented involves further decisions which affect the resource implications for construction, levels of technical skill and stability of the structure. These decisions - and how effective they were in allowing a building to stand for a generationare tested by this long-term experiment. The timber species used for the different parts of the structure are set out in Table 1.

The walls of the roundhouse consisted of uprights in shallow postholes set in the foundation gully, joined together by wattling and covered with daub. Reynolds (1995) has argued that the wall gully commonly encountered archaeologically was not part of the construction method, but that individual set uprights within the wattle walling were joined together with a slightly sinuous gully created by rodents burrowing

Table 1 Timber species used in the roundhouse reconstructions

\begin{tabular}{lll}
\hline Structural element & Cookhouse roundhouse & Earthwatch roundhouse \\
\hline Major wall uprights & Oak & Oak \\
Inner post ring & Oak & N/A \\
Ring beam & Oak & Oak \\
Door posts & Oak & Oak \\
Wattling for walls & Hazel & Hazel \\
Major rafters & Oak & Larch \\
Other rafters & Oak & Oak \\
Purlins & Hazel and willow & Hazel \\
\hline
\end{tabular}

along under the wall line. It is notable, however, that at Castell Henllys, there was no evidence for rodent activity creating runs under the wall for either excavated reconstruction roundhouse, though other rodent activity has been identified and is discussed below.

The postholes and foundation gully were recut where the originals had been, but deeper to account for an estimated loss of the original surface. As there was an inner ring of roof supports, joined together by a ring beam formed of lashed timbers set in natural forks in the uprights, it was decided that there was no need for a wall plate running round joining the uprights in the wall together. The wall uprights were not in deep-set postholes, but once the hazel wattling was woven between the uprights, the tension ensured a rigid cylinder, made more substantial by the application of the daub from both the interior and exterior of the roundhouse (Mytum 1986). The interior ring beam distributed pressures around the structure, and the rafters came down and were notched and lashed onto the uprights which were visible just above the wattle and daub wall. Some rafters ran right up to the apex from the wall, but others only went as far as the ring beam, and all were joined by thinner horizontally placed purlins. This lack of a wall plate saved a lot of time and labour and meant that the skills level for constructing the whole structure could be low. Various mixes were tried for the daub, with water and clay having different combinations of straw, horsehair and manure added, but these do not appear to have had any notable impact on survival and maintenance over time. One significant archaeological signature of the daubing process was a trampled humic layer that formed on the exterior of the wall and then protected by the eaves of the roof (Fig. 3).

As the two door postholes were so massive and each held a deep-set timber upright, it was decided that the door lintel would be higher than the rest of the wall, creating an easier entry to the building and a change in angle for the roof at this point. The lack of wall plate did not create any difficulty with a raised door. The doorway faced southwest, and being larger in size, also increased natural light into the interior when the door was open (Fig. 4).

The roof was formed from radially placed rafters and concentric rings of purlins onto which the bundles of reed thatch could be tied. The apex of the roof was covered by a separate cone; this weathered rapidly but could be easily replaced with another, made on the ground and then dragged up the exterior and pegged into place with loops of flexible coppiced hazel rods. The eaves of the roof came close to the ground, both protecting the walls from erosion and creating a storage space under the eaves. On the northern and western sides of the site, the original excavation identified an eaves drip gully parallel with the wall line which had been a key piece of information in deciding how the wall height and angle of roof would correspond with the archaeology as the lowest point of the eaves had to be positioned above the gully. This gully was dug in the 
Fig. 3 Plan of Cookhouse phase

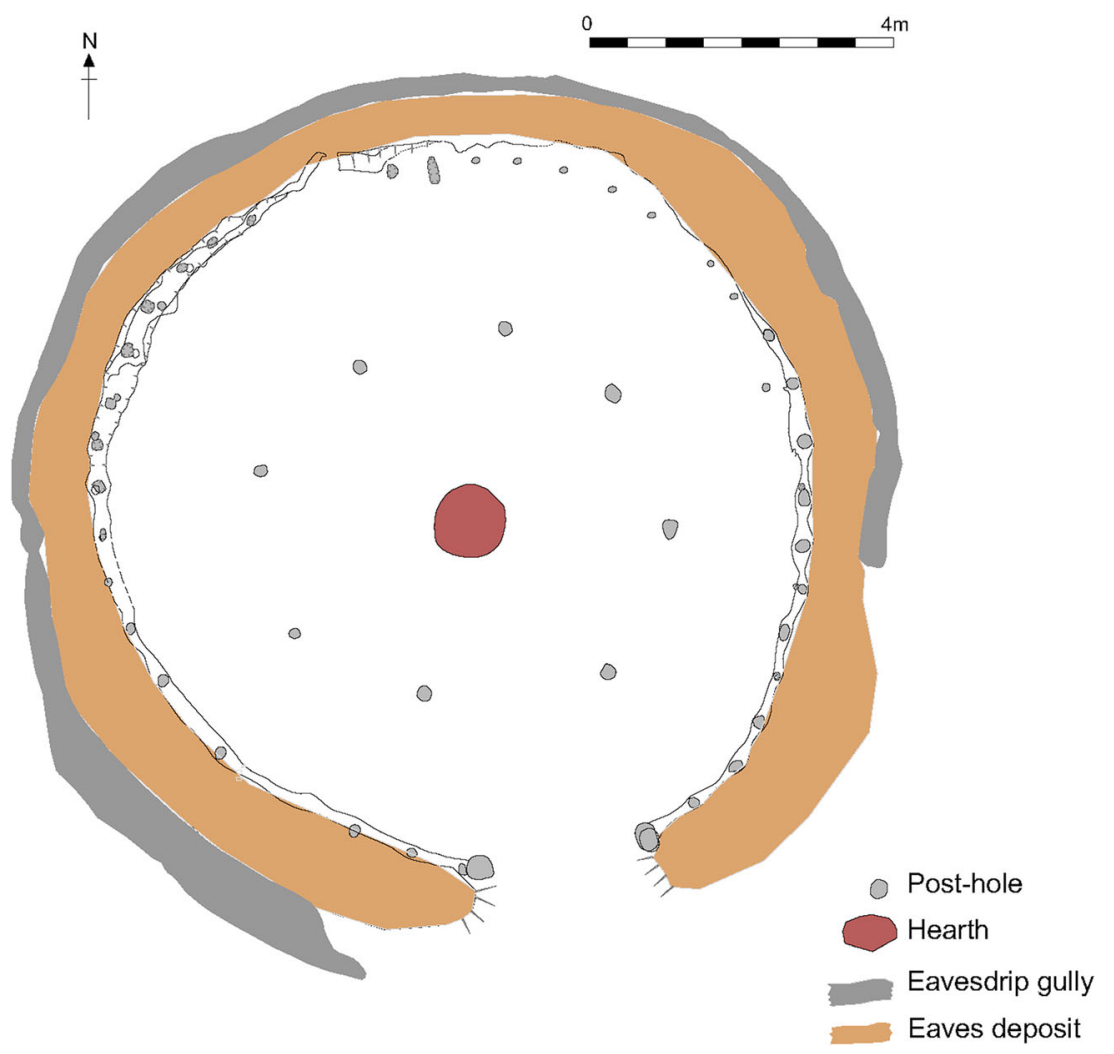

original reconstruction (Fig. 3), but it was not maintained, and phase 2 of the roundhouse indicates the roundhouse arrangement after only a few years (Fig. 5) where the gully was silted up. Finds from within the gully relate to the earliest years of the site use, and they included plastic discs (Fig. 6a) that were tied onto the bundles of the thatching reed that were imported from Hungary to complete the thatching after locally sourced reeds proved insufficient (Mytum 1986).

A central hearth provided heat from a wood-burning fire was carefully tended by the interpretation staff, with the smoke filtering out through the thatch. This was initially a

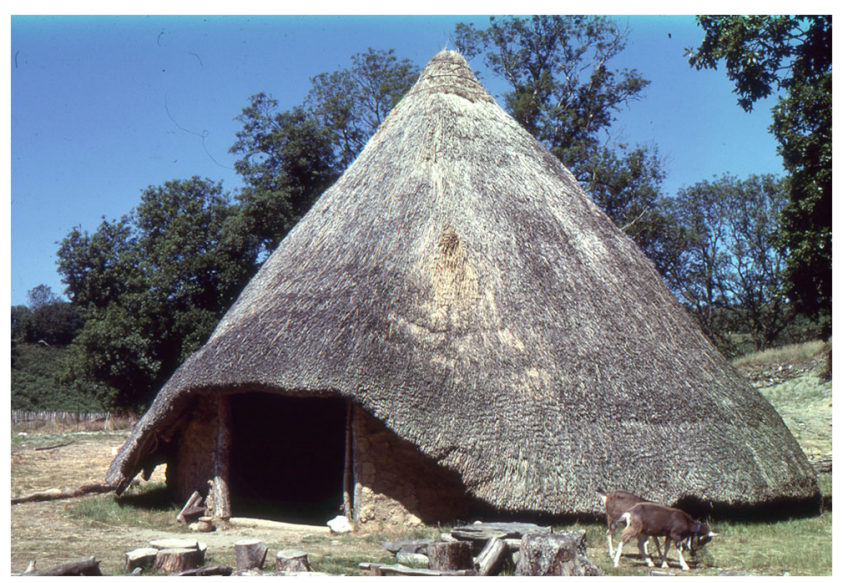

Fig. 4 Cookhouse phase 1 from southeast, taken 1984 roughly circular hearth form without any formal edging, inspired by the excavated evidence (Fig. 6b). In phase 3 of the roundhouse reconstruction, this was replaced with a square design with upright shale slabs on the exterior and interior, creating a central space for the fire. This was not experimental in that it was not suggested by the archaeology. Its inappropriate design was rapidly demonstrated by its colonisation by rats which burrowed into the lower levels; this form of hearth left a distinctive archaeological signature, and rat skeletons were found in the burrows during the excavation following demolition. This demonstrates that this form of hearth was not used in the remote past and why. Whilst in use for a decade, there had been no infestation with the circular clay hearth set on some horizontally laid shale slabs.

Benches near the hearth provided seating for visitors to feel part of the atmosphere, and three beds were placed in the outer space between the wall and the inner ring of posts. The central bed had a mattress raised on a wooden frame, but the ones either side had mattresses directly on the ground. In an attempt to improve the light levels within the roundhouse, the walls were painted with lime wash - this greatly enhanced visibility. There is no archaeological evidence for this being done, but given the remains found, and the acidic soil conditions, no such evidence would have survived at this site. At various points, designs were painted on the walls to create a cultural resonance of the Iron Age by using La Tène style motifs; at one phase of roundhouse interior design, some replica metal 
Fig. 5 Plan of Cookhouse phase 2

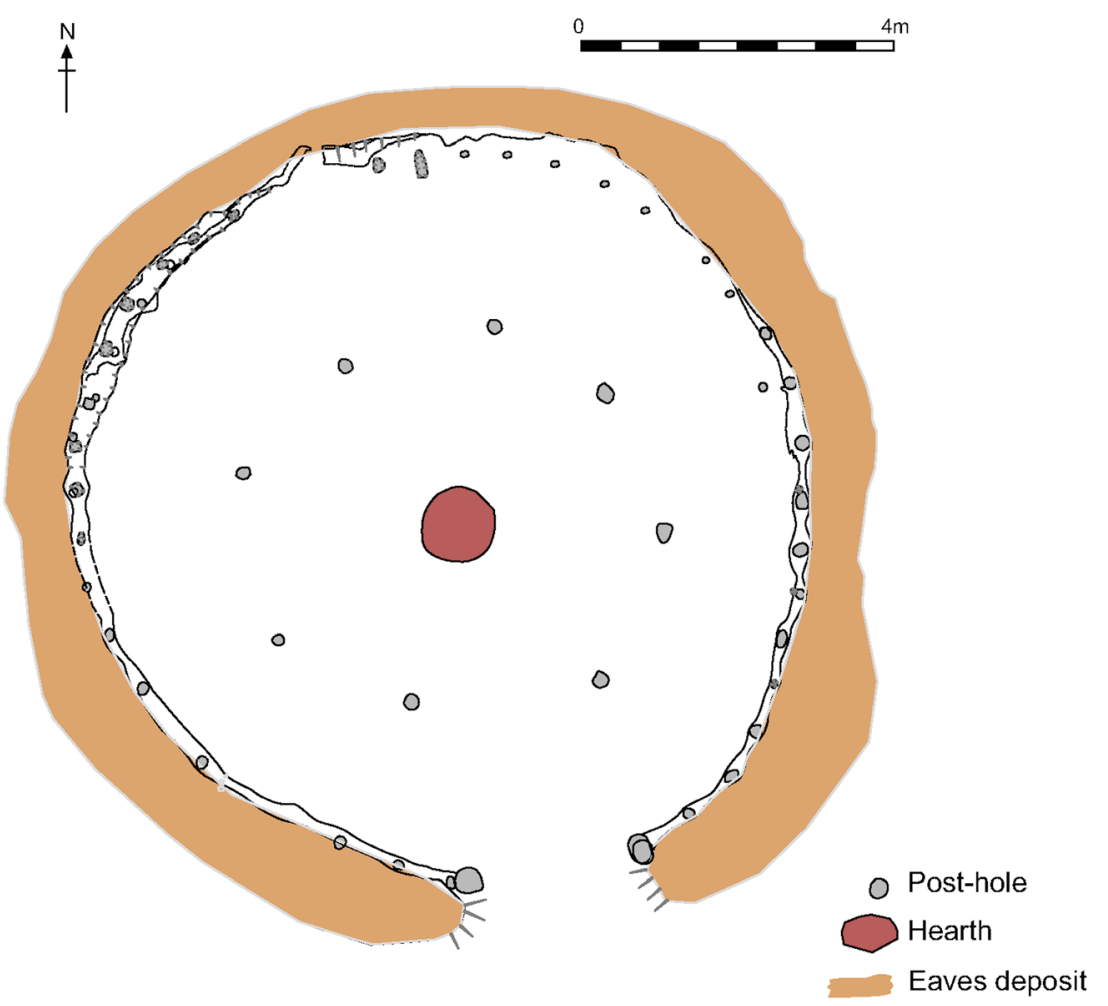

plaques with La Tène designs were nailed to the inner ring upright, but they were not maintained in the long term. These various decorative elements have heritage implications but are not part of the structural experiment (Mytum 2003), though they have some signature in the re-excavation evidence.

Activities within the roundhouse included grinding grain on a replica rotary quern, cooking and storytelling. A portable loom was occasionally worked outside the roundhouse by demonstration staff, but stored when not in use, leaning against the interior wall of the building to the west of the doorway. When the National Park instigated their education programme in 1993, school parties would come into the roundhouse for part of their visit, though they would spend more of their time outside or in the roundhouse discussed below. Many of the children had their faces painted with spiral designs, usually in blue face paint to simulate woad; this activity often took place immediately outside this roundhouse. Non-school visitors could wander around the site in an order they chose, spending as long as they liked in any part of the site. Observation of visitor behaviour revealed all would enter the roundhouse, with most circulating round the house between the hearth and the inner ring, though some would venture into the outer areas to observe artefacts or the wall construction or decoration.

The roundhouse stood for 35 years, maintained by having its thatch and external daub patched when necessary, and the roof was re-thatched in its entirety twice, though only a small amount of new reed was required each time as much of the old materials could be re-used. Once standing, the roundhouse did not require much in the way of new materials to maintain it. A fire was in use during most of the life of the house, though for a short period, there was no fire when the rethatching had been done too tightly and the smoke could not escape through the reeds. Only during this time did birds nest in the roof, which was quickly re-thatched more loosely and no birds or mammals ever infested the roof under these circumstances.

After over 20 years, the front part of the wall line and the inner ring of posts was replaced in phase 3 (Fig. 7), sadly by over-engineered timber set in postholes much larger in diameter and far deeper, and packed with rammed clay, quite unlike that indicated by the archaeology (Fig. 8a, b). The roof was jacked up whilst this took place. Despite this effort (or perhaps in part at least because of it), the building subsequently developed a twisted roof, and small lengths of timber were set upright on flat stones that were placed under the ends of the rafters outside the wall line which helped prop the building in place (Fig. 9). This created a different archaeological pattern, with the flat stones overlying the infilled eaves drip gully but were also ranged all round the structure, creating a distinctive signature for phase 4 (Fig. 10), with other timbers added to the roof in an attempt to prevent further movement. However, the roof continued to slump slightly to the south-east, to the extent that in the last year some of the rafters rested on the ground (Fig. 11), and the National Park decided the building was unsafe. Although the structure could not collapse any further, and the wall and the roof itself were both intact and sound, 

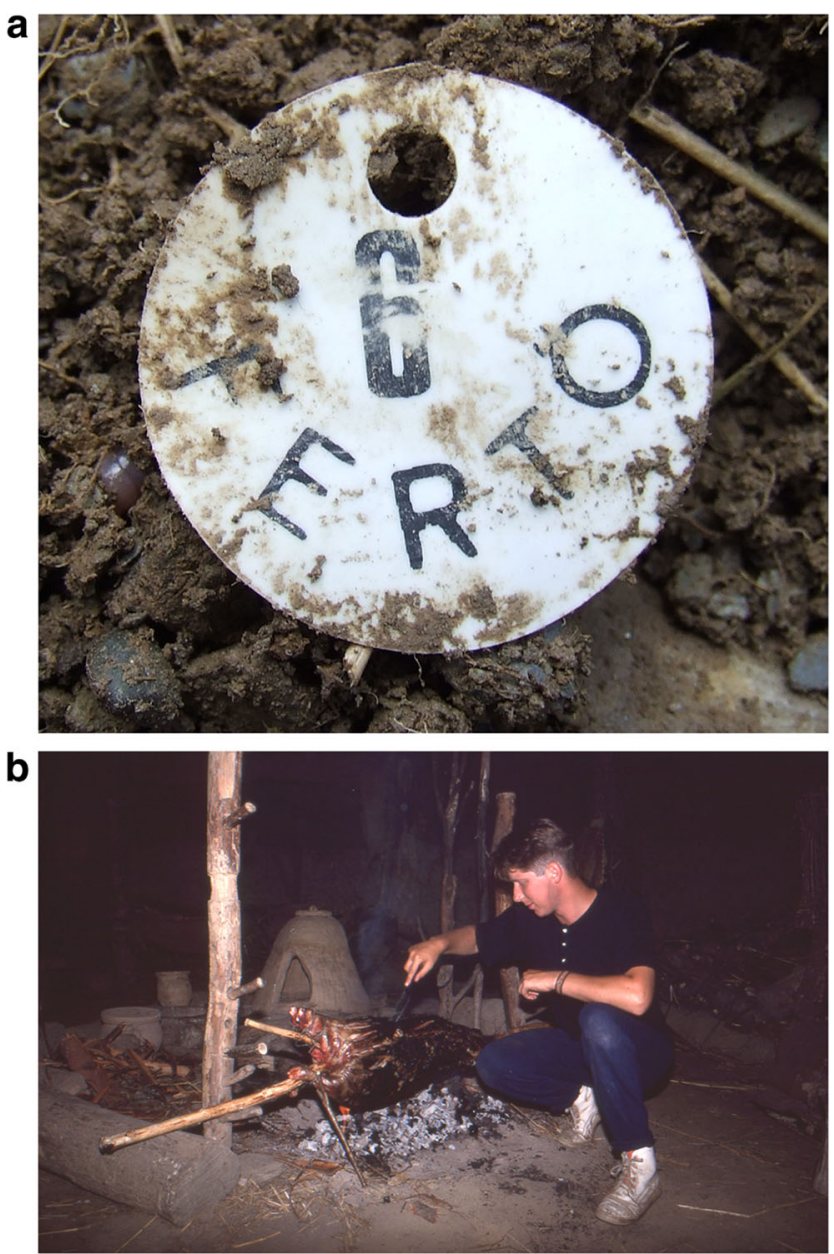

Fig. 6 a Hungarian thatch tag from Cookhouse construction phase. b Hearth as reconstructed in Cookhouse phases 1 and 2

modern as opposed to prehistoric views of safety meant that it was no longer possible to enter the building. It is highly likely that in the past, the building would have continued to be occupied and could have been adjusted on the next re-thatching (when the weight of the roof is least, and it is easiest to adjust both the wall and roof components). Given that the wall was stable, and the roof required only readjustment, it is possible that the building could have lasted for one or more decades longer, but it was decided to demolish and rebuild the structure. After 35 years, this roundhouse was taken down, thus presenting the opportunity to excavate the site once more.

\section{Cookhouse roundhouse demolition and re-excavation}

The roundhouse was photographically recorded prior to and during demolition, allowing a 3D model to be created (Fig. 12). This was followed by a community excavation arranged by Dyfed Archaeological Trust in conjunction with the University of Liverpool so that local people and students could collaborate on investigating this unique site (Mytum and Meek 2019). Funded by the National Park, the project was designed to learn lessons so that the replacement roundhouse could be appropriately adjusted in its design, and so that the evidence from a twentieth to twenty-first century roundhouse could be compared with that of Iron Age excavated examples. The whole of the interior and extent of exterior activity including the eaves drip gully were all cleaned and defined, all structural features were completely excavated, eaves drip gully $70 \%$ excavated and all identified internal deposits were mapped and sample excavated.

The wall before the removal of the thatch was an intact daub wall which was structurally sound, albeit with cracks in the surface of the daub. After the thatch and rafters were taken off, parts of the walling rapidly collapsed as the rain weakened the daub. The daub initially slumped down the wall faces, exposing the already dry and weak wattle. The original upright timbers, rotted at ground level (see below), then fell over where the slumped daub was insufficient to hold these in place (Fig. 13). The wall collapse therefore created a mounded clayey deposit with high humic content along the line of the wall foundation, though with patches of wall falling, still attached to posts and wattle panels, away from the wall line. Parts of the wall were still standing when the excavation commenced, so this was carefully dismantled in the first part of the excavation. The wattle in the replacement wall section was still flexible and was in remarkably good condition, but the uprights, although intact, were already showing clear signs of rotting through at ground level. Those uprights from the original building were completely rotted through - the wall was by this stage largely a daub structure, and the timber uprights in this section was not providing any structural support, but the wall functioned perfectly wellthis had not been the problematic part of the building.

The archaeological signature of the original reconstruction roundhouse was remarkably similar to that of the prehistoric data. The wall gully and postholes contained the remains of the completely decayed posts, still more humic than in the prehistoric examples (where the deposits would have leached in the long term) but otherwise very similar in size and shape. Rodent activity was visible in and around many of the postholes (Fig. 14). Reynolds (1995,3) had found that wall posts were joined together by a rodent burrows running round directly beneath the wall, creating an apparent gully. This was not seen at Castell Henllys; the gully portions did not appear to be occupied, but in contrast the postholes of the central ring were affected by rodent activity. Either the soft wood or the completely decayed bases of the wall posts were in several cases used by rodents as locations for nests, with the soft deposits easily removed, and the intact post above-ground and the still in situ vertical shale packing stones providing stable sides for any nest. These therefore largely kept the shape of the postholes, but in some cases, access to the nests also involved also burrowing into the subsoil beyond the 
Fig. 7 Plan of Cookhouse phase 3

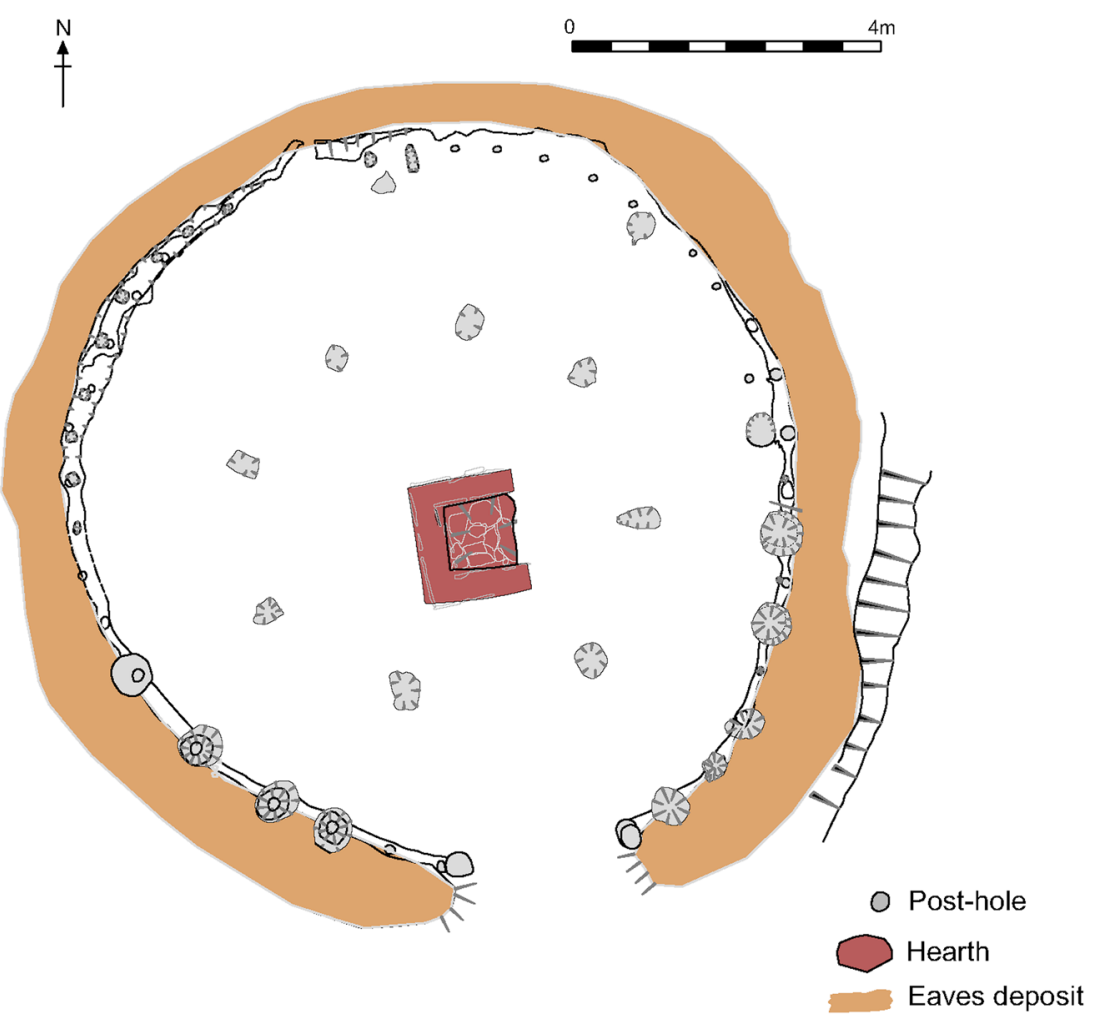

packing. A small number of artefacts were found within these burrowed posthole fills, but this is more common in the second roundhouse and this phenomenon is discussed in the detail with reference to that structure. This effect of postholes modified in shape by burrows has been noted for prehistoric postholes elsewhere at Castell Henllys, especially when the variable subsoil is soft gravels. It should be remembered that two of the original postholes for the inner ring of posts were not identified because of animal disturbance; this finding explains why these locations were disturbed and could easily have been completely eradicated if they had not incorporated any shale packing stones. The wall uprights and inner ring posts survived in relatively good condition above-ground, and they could be removed and recorded (Fig. 15). In prehistory, they could have been reused, albeit c. $0.3 \mathrm{~m}$ shorter than in their first use life.

Excavation revealed how the deliberately dug eaves drip gullies gradually filled up with debris (dust and leaves which
Fig. 8 a Excavated wall line postholes from Cookhouse phase 1 reconstruction. b Excavated wall line postholes from Cookhouse phase 3 reconstruction a

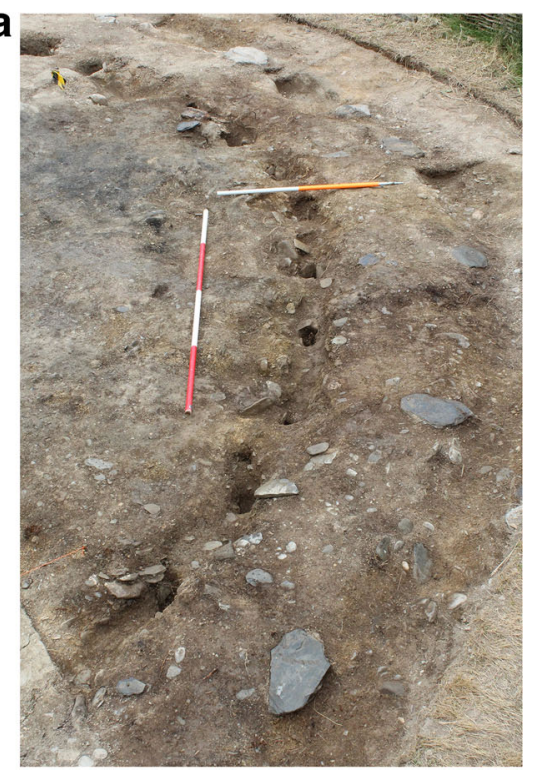

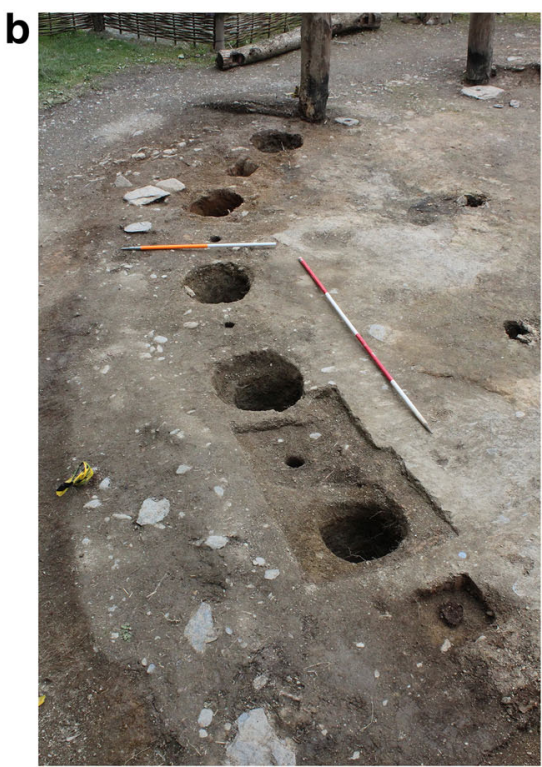




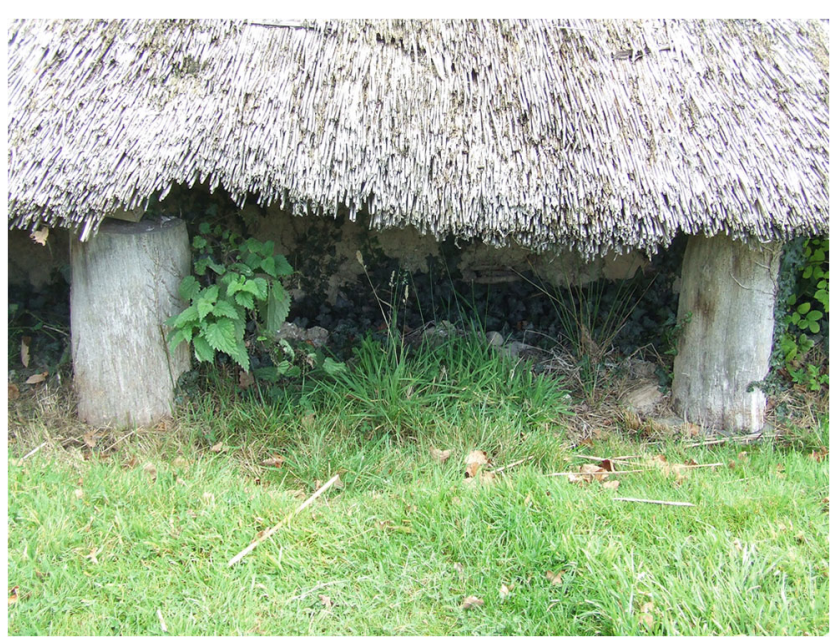

Fig. 9 Cookhouse Phase 4 wooden rafter props set on flat stones

decayed to a humic loam), and where they were cleaned outa process not maintained through the whole life of the roundhouse - they were not always dug on quite the same line and depth. Indeed, within the gully, some of the plastic discs were discovered that had been attached to the bundles of thatch that had to be imported from Hungary at short notice when Hugh Foster discovered that not enough local reed had been harvested to complete the roof. These had survived in the eaves drip gully fill for 35 years and represent items from the construction phase of the building. There were also other items including a replica perforated stone used as a loom weight in the reconstructions that belonged to the earliest

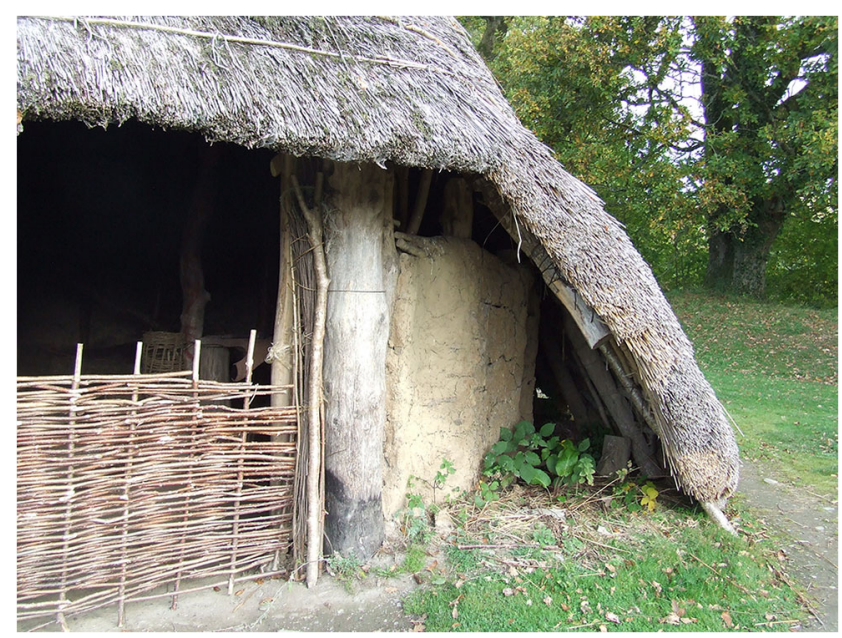

Fig. 11 Cookhouse Phase 4 rafters resting on the ground to east of doorway

phase of use (Fig. 16), and evidence of visitor presence such as coins and sweet wrappers were also found, though not in large numbers because the infilling was relatively rapid.

In the space between the outer face of the wall and where the thatch roof came close to the ground, deposits accumulated. These were probably partly remains of daub that was unused during construction or maintenance and had been trampled into the surface by those daubing the wall. Some daub may have fallen off the walls, and small amounts of daub maintenance took place when the thatch was taken off before the roof was re-thatched. The deposit also comprises leaves and dust that had blown in and settled in these protected
Fig. 10 Plan of Cookhouse phase 4

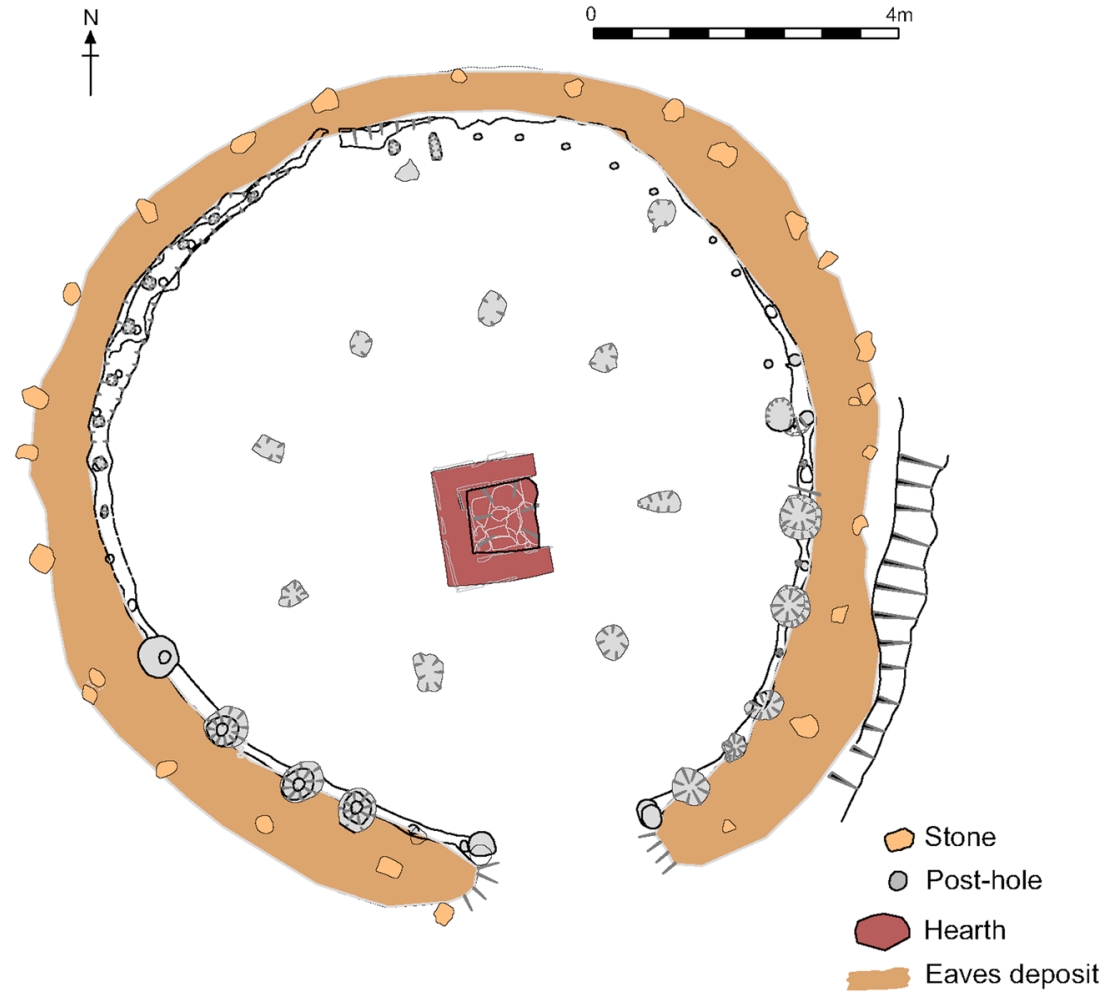




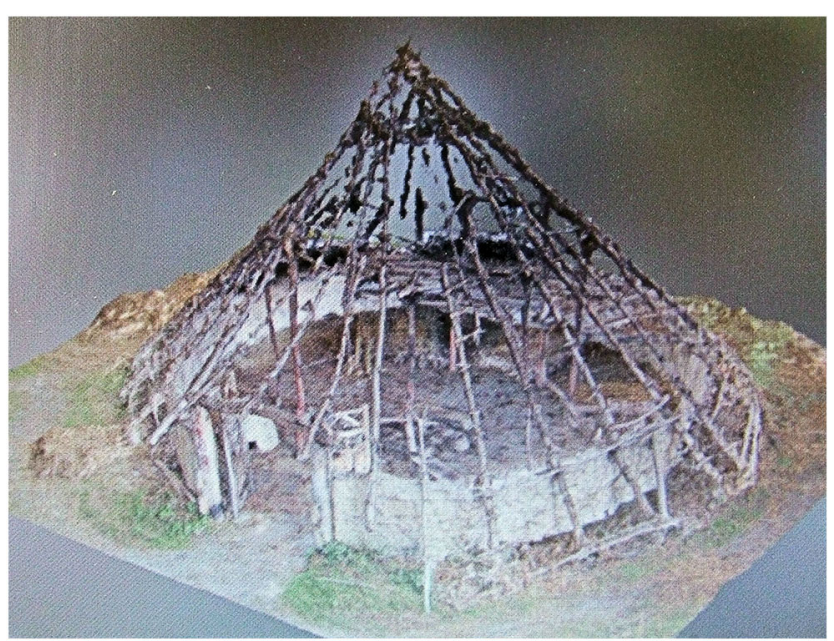

Fig. 12 Sketchfab model of the Cookhouse whilst being dismantled

locations over the 35 years; the leaves would decompose, and only the more recent introductions were still identifiable, but this shows how this protected micro-environment could create a distinctive deposit up to $0.03 \mathrm{~m}$ thick as an annular ring around the wall line (Fig. 17).

Many people came in and out of the roundhouse over its life - visitor numbers have consistently been between 10,000 and 15,000 per annum. No specially made floor was initially placed over the excavated subsoil, and differential use of space within the building created distinct areas of accumulation and erosion within the roundhouse. The replacement reconstruction roundhouse has used some of the information from the excavation, but despite a 35-year life of the original reconstruction, the structural engineers advising the National Park would only agree to a reconstruction with larger uprights than used previously. In order to match the archaeology, the parts below-ground were narrowed down, but that makes the use of thicker timbers even more unfortunate, as well as making the wattling for the walls particularly difficult. This new reconstruction has already indicated why a number of

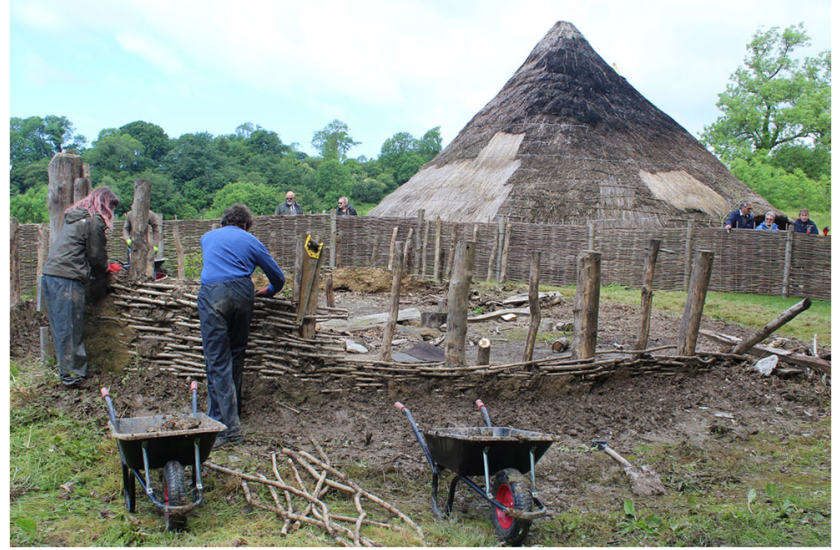

Fig. 13 Partially standing Cookhouse wall with wattle and daub and slumped wall materials

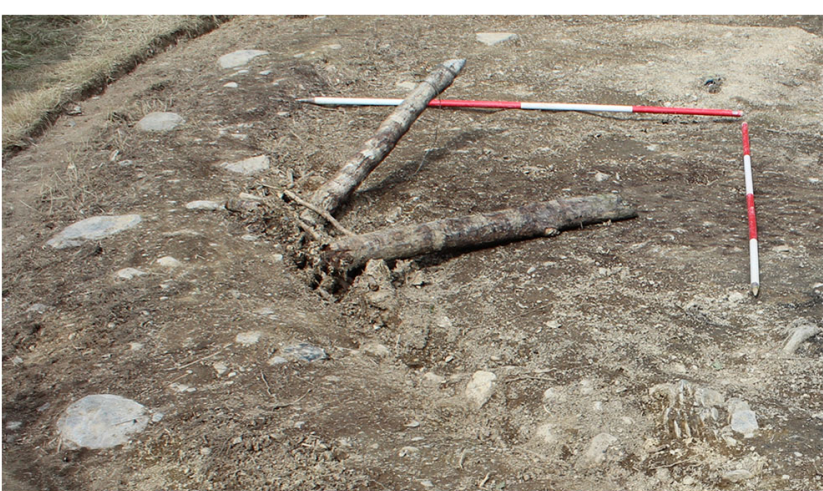

Fig. 14 Decayed posts in postholes on the wall line of the original Cookhouse reconstruction; part below ground to the right

decisions made by twenty-first-century engineers were not made in the Iron Age even if they create a more stable building over the long term. The problems in identifying and moving such large timbers to the site (before the availability of dieselpowered vehicles) would have been substantial. The construction of wattle and daub walling incorporating the large wall posts was extremely difficult as the uprights were too wide to make the weaving of the wattles around then effective.

\section{The Earthwatch roundhouse excavation and reconstruction}

The archaeological remains that would provide the data for the Earthwatch roundhouse reconstruction was excavated in 1984, immediately north of the Cookhouse reconstruction which was by this time fully operational. After mechanical removal of the topsoil, initial cleaning of the subsoil surface indicated the circular foundation trench of the roundhouse. There was no eaves drip gully, and the house was set on ground that had a significant natural slope from north to south. Partially surviving gullies of other roundhouses of a different phase were also located immediately to the east, together with postholes and small pits which could not be stratigraphically linked to any phase of structures, though as some would have blocked the entrance into the Earthwatch roundhouse, they must have been of a different date. From the plan, the surviving postholes did not indicate any internal concentric ring. The doorway, relatively wide, was on the eastern side of the

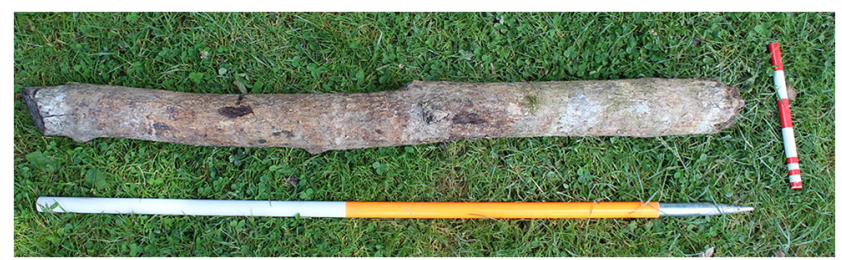

Fig. 15 Timber removed from original Cookhouse reconstructed wall, with part below ground missing 


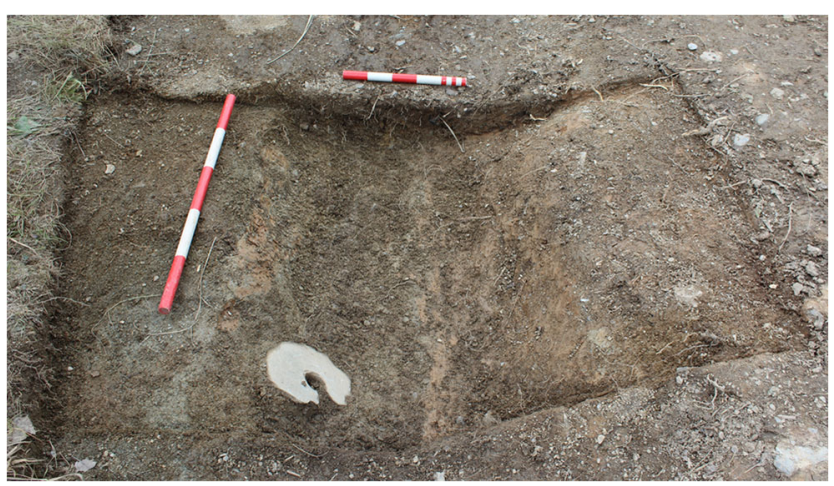

Fig. 16 Filled up Cookhouse eaves drip gully under excavation, exposing a replica perforated stone

structure, though part of the western wall line had been disturbed in the past by a badger sett which had created a distinctive fine gravelly area where the burrowing had occurred. It is therefore possible that there was also a western doorway but, given the lack of firm evidence and also practical issues with a door in this location related to wall height (see below), the most likely interpretation is that there was only the single outer door. Most roundhouses only have a single entrance point, though a small number do have two, usually opposite but very rarely offset (Harding 2009).

The significant feature of the roundhouse excavated evidence is the character of the wall foundation. Apart from the disturbed area, it was complete, but varied considerably in depth though not width around the circuit. To the north, the trench was very shallow, only $0.10-0.15 \mathrm{~m}$ deep, but on the southernmost part of the wall line, it reached a maximum of $0.6 \mathrm{~m}$. The difference in depths was most obvious either side of the doorway. This construction design is unique in later prehistoric roundhouses in Britain but can be explained by the nature of the site topography. The relatively steep slope was not ameliorated as was the case elsewhere at Castell Henllys (Mytum 2013) and as usually found elsewhere in Britain by the excavation of a scoop into the soil to create a horizontal platform on which the roundhouse could be erected

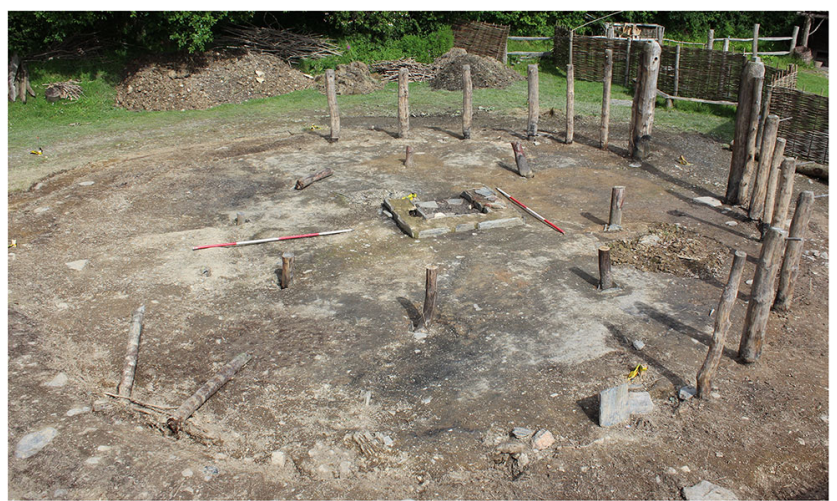

Fig. 17 Excavation exposes the occupation deposits that accumulated within the Cookhouse roundhouse (a technique also applied at Castell Henllys itself). Instead, the wall must have varied considerably in height around its circumference to create a horizontal and therefore structurally effective wall plate on which the conical roof could be placed. To achieve wall stability the unusually low walling on the uphill northern side the foundation trench could be shallow, but on the lower southern side, the exceptionally tall walling required a deeper foundation.

The roundhouse was therefore constructed with each upright cut to be of a length to match the location round the circumference. The timber species used for the different parts of the structure are set out in Table 1. The wall foundation trench was dug slightly deeper to take account of eroded ground surface and, in order to facilitate assembly of this unexpectedly complex design the posts were bedded slightly deeper than the wall trench, though this was not archaeologically attested. The trench was filled by a dedicated team ensuring the posts remained upright and before any wattling of the wall was possible. In the reconstruction, the wattling was completed before the wall plate was put in place as the tension in the hazel wattles made the wall extremely stable. The tops of the upright wall posts were then cut to make the pegs for the sections of wall plate to be slotted into place (Fig. 18).

The wall height was decided on the basis of the minimum sensible height on the uphill side and what was viewed as the maximum height of the downhill, given the implications for the roofing discussed below. One implication of the wall height decision was that the door on the eastern side was relatively low. It was also relatively wide, and this at least slightly increased the natural light into the house but facing to the east meant that the interior was much lower light levels than the Cookhouse roundhouse did with its door facing southwest. The Earthwatch door was spanned by a single lintel, and one with a slight curve was selected to provide a slightly higher central point than would have been the case with a horizontal element (Fig. 19). In order to signal how buildings are not only merely structural but also with stylistic and cultural meanings, designs from locally recovered

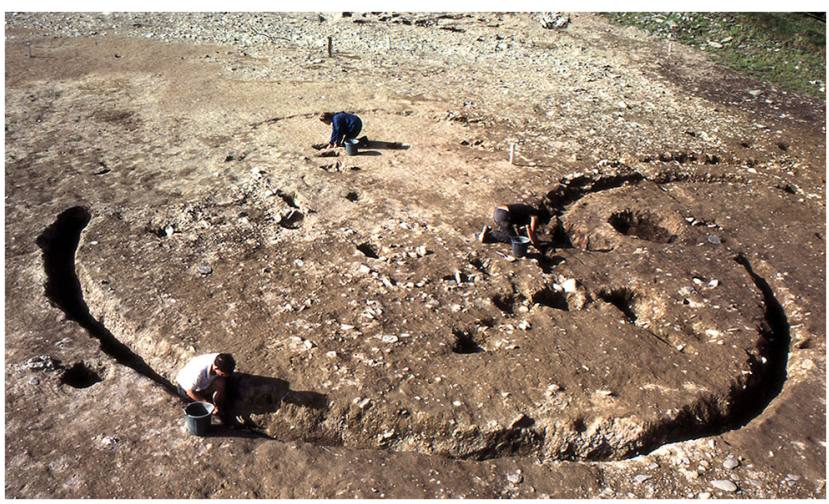

Fig. 18 Earthwatch roundhouse under under excavation, 1988 


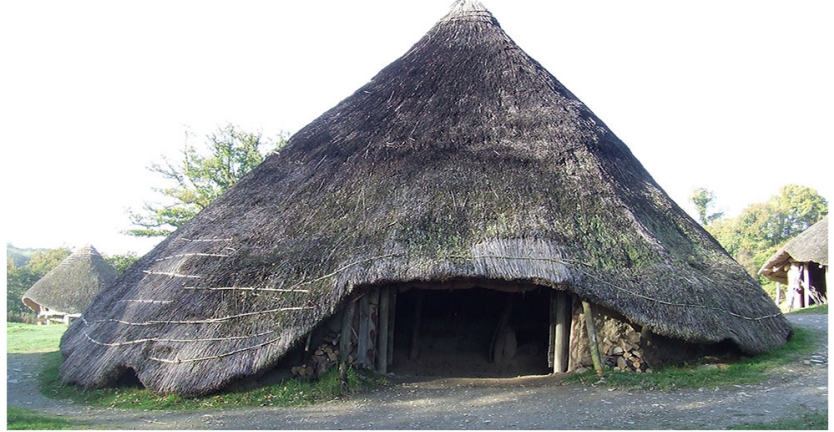

Fig. 19 Earthwatch roundhouse doorway and asymmetrical roof profile, taken 2017

metalwork were carved and coloured onto the uprights, though this did not affect their structural integrity (Mytum 2003).

The roof of the roundhouse in plan was affected by the varied height of the wall, as it came close to the ground at all points. On the uphill side, this meant that the rafters extended only a short distance from the wall plate before they were close to the ground surface, whereas on the downhill side, they were much longer - especially as the ground was sloping away. This created a roof plan that was oval rather than circular and with an asymmetrical profile. It also meant that rafters had to be individually cut to the appropriate length for their position within the structure. The rafters began to be put in place as the daubing proceeded as this gave easier access to the wall surfaces. The long rafters on the downhill side extended a considerable distance from the wall plate and, particularly, when weighed down with thatching created a tension in the rafter timbers which was remedied by the use of angled timbers which ran from the exterior base of the wall and rested on the underside of the relevant rafter at an angle which helped support the weight of the thatch. These were wedged in after thatching, but they were no less effective for this. The door was constructed with two leaves which were set in shale pivot stones next to the door jambs. The area beneath the thatchwhich appears asymmetrically in plan - also retained the trample from daubing and other debris, as had been the case with the Cookhouse (Fig. 20). A central oval hearth was surrounded by movable benching, though a practicable arrangement of the seating was soon developed which was then maintained over all the remaining phases.

One experiment with the roof of the roundhouse which was shown to be unsuccessful was to have no suspended ring beam with any significant structural role. This created both congestions at the apex where many rafters came together at this point and also meant that more long timbers were required than would otherwise have been the case. As a result, the site owner decided to use larch for the rafters, a species that would not have been available to the original constructors. This had a further side effect on the building in that larch is a relatively flexible timber, and so the rafters bowed under the weight of the thatch and bent further during high winds. Though structurally sound this was viewed with alarm by the National Park when they took over control of the site. The obvious solution would have been to insert a suspended ring beam after taking off the thatch. This, fixed below the rafters, would have prevented them bowing. However, instead posts were wedged against the rafters and set on flat shale slabs placed on the ground surface (Fig. 21). This would have left no archaeological signature so may have been the solution if the problem had been perceived in the past, but it created a completely different visual effect within the roundhouse and affected how those using the building separated space into that within the uprights and outside it. This matter is being reviewed and is affecting the design of the new reconstruction (see below).

A further challenge with both understanding how the original structure would have functioned, and how to reconstruct it, is the effect of the natural slope of the ground within the roundhouse. Cutting a scoop into the slope creates potential problems with water entering through the uphill walling of the house, but the horizontal floor makes use of the internal space straightforward. With the Earthwatch roundhouse, the practical implications of the slope rapidly became clear. Not only was the wall very low on the uphill side, making use of the perimeter space on that side extremely limited, but the slope also made the carrying out of many activities within the roundhouse difficult. Once the props for the rafters were in place, the interior uphill of this ring was rarely accessed. That to the south, downhill of the props, was also less used, and the original owner infilled this area with some bark chippings. In due course, the National Park instigated two successive phases of floor-raising in this area to create a more effective use of space within the roundhouse to house benched seating (Fig. 22). One notable feature of these floors being inserted was that the props became surrounded by flooring and so on dismantling there were postholes visible, created not by cutting these into the surface but by the surface being raised around them. Thus, the props became archaeologically visible as ghosts even though in their original design this was not the case, and those on the uphill side where there was no raising of the floor still left no trace, as they still sat on the stones that remained on the surface (Fig. 23).

The creating of the ring of props focussed public use on the central area in which the National Park constructed a circular raised hearth made from drystone shale walling. There was no archaeological evidence for such a feature, though given that it had no below-ground foundations, it cannot be excluded as a possible feature. Around the hearth was permanently placed a ring of timber benches, together with another against the southern inner wall; none had any subsurface trace. These seats were used by the public to sit in the roundhouse and enjoy its peaceful, if rather dark, atmosphere (Fig. 24). It was also the location of storytelling to school parties who sat on the benches, and the location of children's lunches when it was too wet or cold to eat outside. Given the heavy footfall 
Fig. 20 Plan of Earthwatch house phase 1

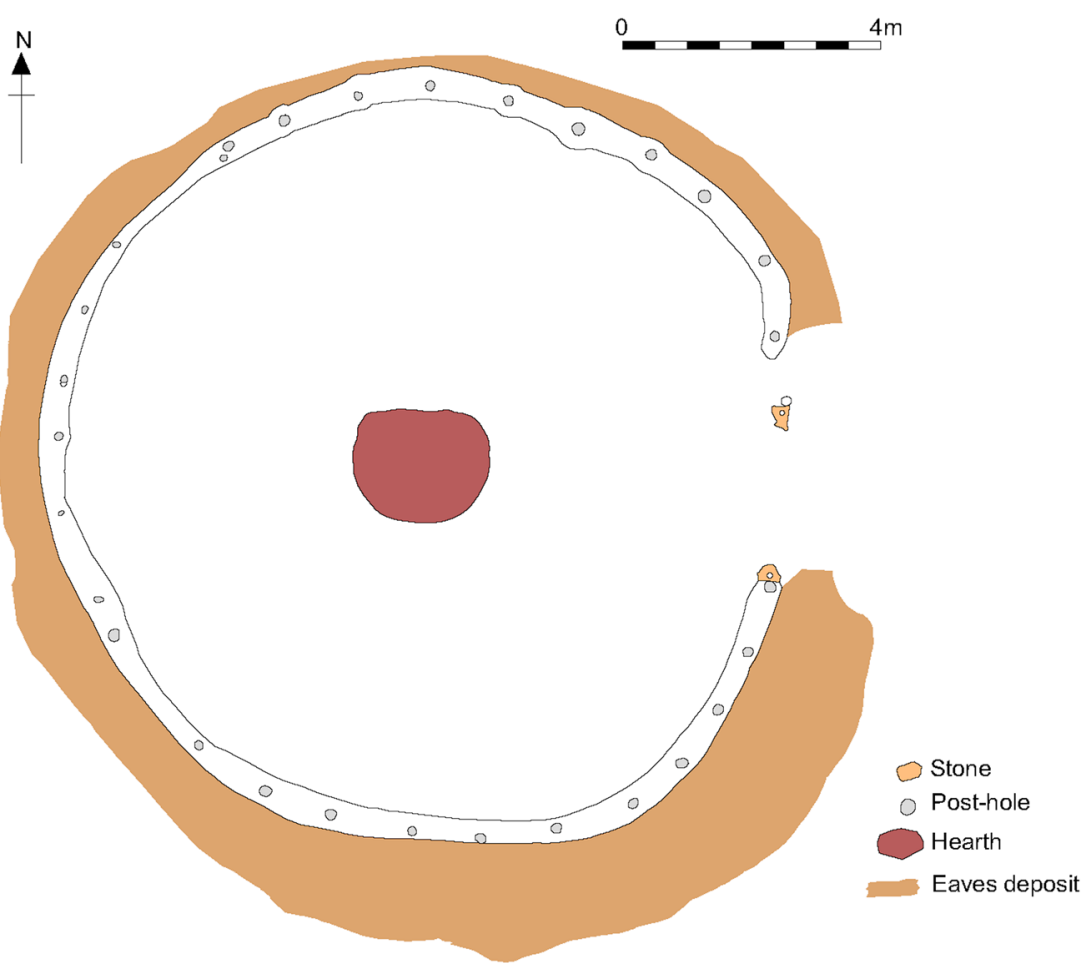

around the hearth and the relatively soft gravel subsoil in some areas, there was considerable abrasion of the surface and wearing away of the floor in this area, and despite some patching and infilling, this problem persisted, creating archaeologically visible depressions that were not part of the original evidence. This suggests that the concentrated wear around the centre of the structure was not comparable with that of the past or that more resilient flooring, suitably maintained but eroded after abandonment, would have been applied. It is possible that much more substantial infilling and raising of floors, possibly even with a stepped arrangement, may have been created inside the roundhouse in later prehistory. On ancient
Fig. 21 Plan of Earthwatch roundhouse phase 2, with stone pads on which props for the rafters were placed

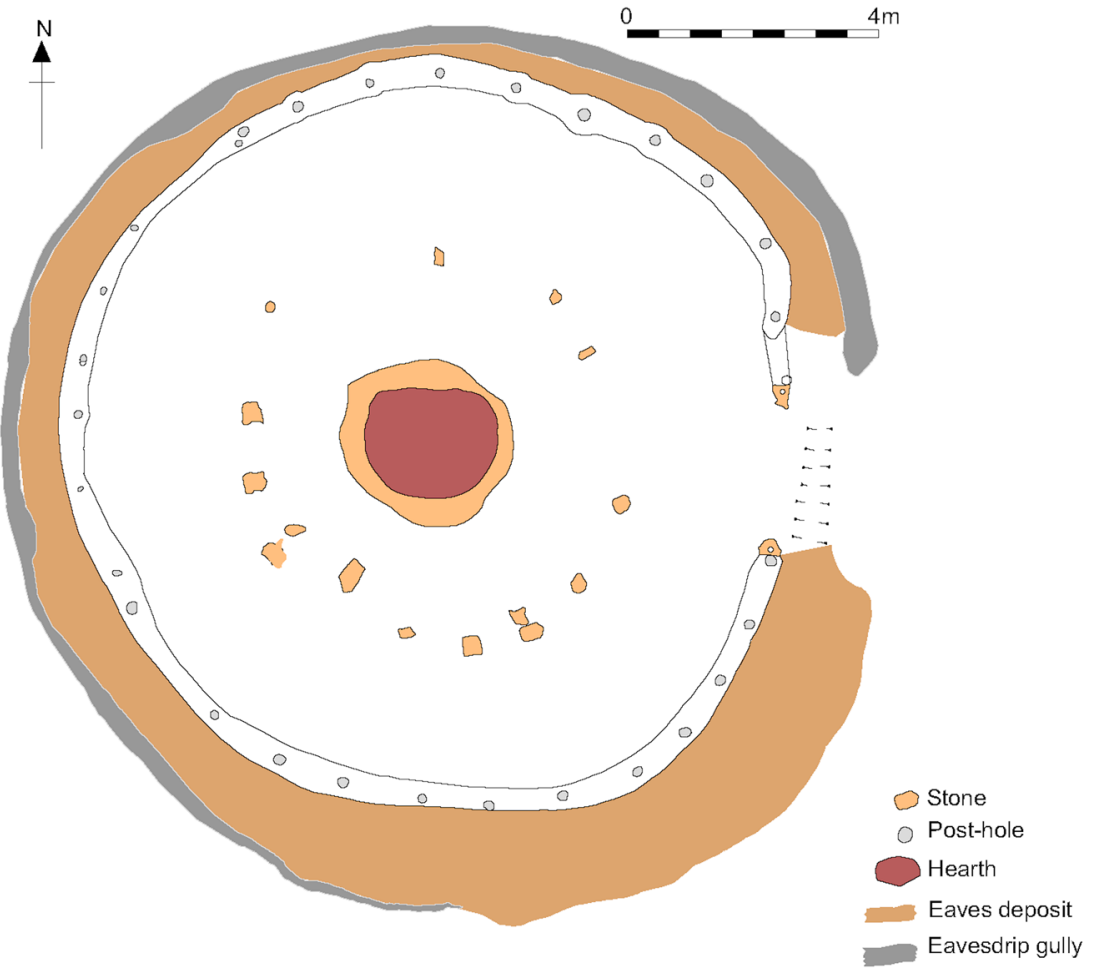




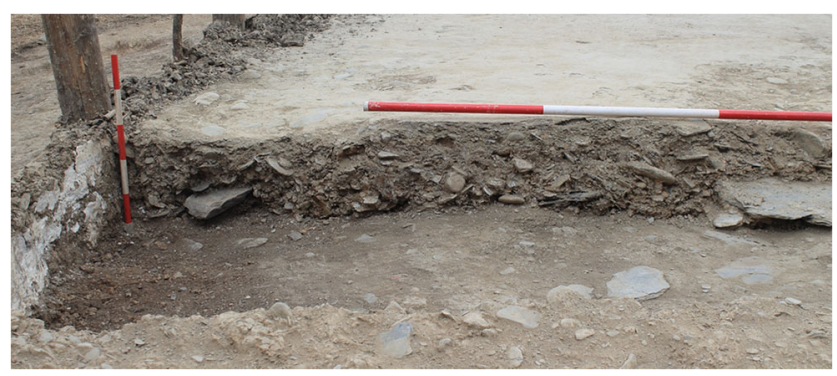

Fig. 22 Deposits raising the Earthwatch roundhouse floor S of the central hearth and against the wall

abandonment of the site, these deposits would have rapidly eroded so the lack of evidence on this matter is not significant. The flooring could even have been stepped wooden boarded floors, with the upper edges resting on the surface and leaving no subsurface features.

Experimental archaeology can usefully demonstrate not only what may have been possible but also what was not done, or set parameters within which past decisions were made. Indeed, it is only through longitudinal experiments such as this, for all the caveats of density of use, modern footwear and contemporary activity patterns, that even raises some of the issues which this study has identified. Short-term or lowintensity use experiments have their value, but not regarding long-term attrition from either natural or cultural forces. The former may have aspects which are more easily made equivalent with the past but the cultural, human activities may also be significant and require some incorporation if at all possible within the experimental modelling.

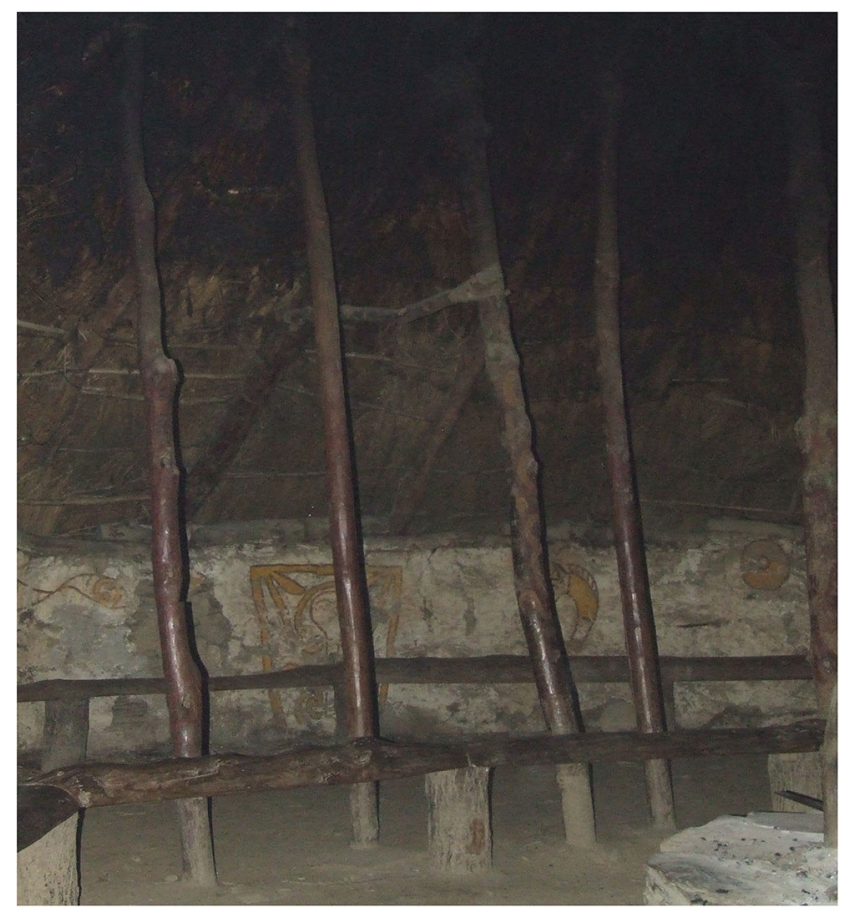

Fig. 24 Earthwatch roundhouse interior with benches round hearth set on the raised floor which has encased the rafter prop bases and hidden their stone pads, taken 2017

\section{The Earthwatch roundhouse demolition and re-excavation}

The Earthwatch roundhouse was photographically recorded in 2017 and was largely dismantled the following year prior to a
Fig. 23 Plan of Earthwatch roundhouse phase 3 , with postghosts where the flooring was built up round the props. On the uphill part of the interior the foot stone pads were retained

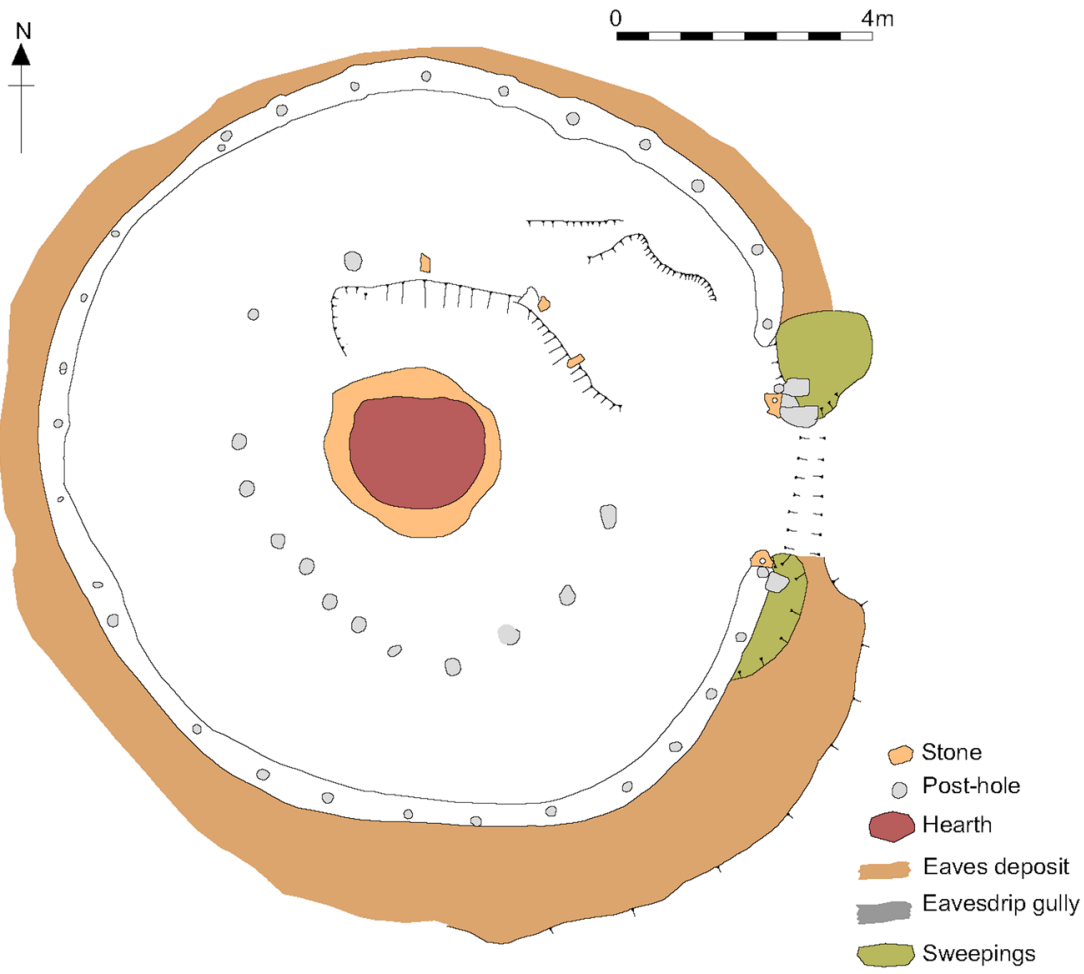


further community excavation arranged by Dyfed Archaeological Trust, also involving students from several universities. It had stood for 30 years and had not been significantly modified apart from the addition of the internal prop timbers and the raising of the floor in the lower, southern half of the interior. The whole of the interior and extent of exterior activity including the eaves drip gully were all cleaned and defined, all structural features were completely excavated, the eaves drip gully was $80 \%$ excavated and all identified surface internal deposits were mapped and sample excavated. The lower levels in the southern portion of the excavation were investigated within the arc of the upright props and towards the doorway and in a 1-m-wide trench excavated through all build-up to reveal the buried wall interior face and the full sequence of deposits in this area.

As with the Cookhouse roundhouse, the building had been routinely rethatched, with the reed roofing removed, sorted and where possible reused and new reed added to replace than lost through degradation and weathering. Although it would have been possible to modify the roof structure during rethatching, this was not undertaken. All the posts in the wall line were as originally used, as were the doorposts. However, immediately, each side of the door additional timber uprights had been inserted to replace others that had rotted to the point of being unstable.

The wall on the northern half had been completely dismantled and removed prior to the excavation, but the higher southern portion remained in place. As the wall had not been rebuilt at any point, it was a valuable opportunity to examine a length of intact 30-year-old walling as preserved beneath the thatched roof. It was notable how the wattle survived within the daub wall to a remarkable extent visually (Fig. 25), but it was structurally no longer effective as whilst the bark remained, the interior had been completely turned to powder by woodworms. The daub had provided the structural integrity for the building as the uprights had rotted away below ground, although the above-ground portions of the wall uprights and the wall plate remained intact, affected by woodworm to a lesser extent that had been the wattling.

The doorway had experienced several different designs of door, always twin doors each affixed to a door jamb because of the door way width and also because of the slope of the ground. Opening outwards was not possible because of the overhanging thatch, and a single large door would have been wedged against the interior rising ground. The doors were set within perforated shale slabs forming pivot stones, and these survived in situ and were archaeologically recovered (Fig. 26), though one was cracked from the pressure of the door's weight and could not be retained. Over the use-life of the roundhouse, additional posts were placed adjacent to the door jambs to support the doorframe, and reused timbers were used as props, though leaving no subsoil mark. As the door was the only place where the eves ended some distance from the

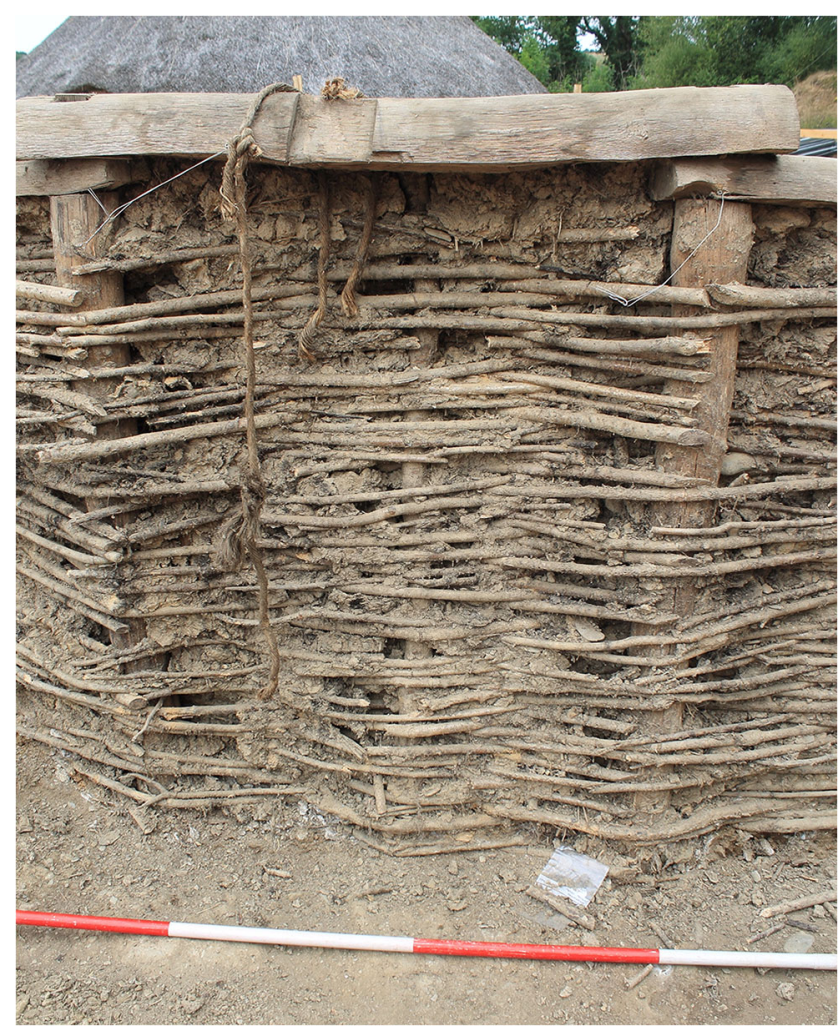

Fig. 25 Earthwatch roundhouse wattle wall exposed after the removal of the exterior daub

ground, and because footfall through the entrance prevented vegetation growth, it is the only part of the perimeter of the building where a slight eaves drip gully formed without any human intervention, whilst immediately inside the doorway wear of the floor surface was substantial (Fig. 27).

The interior deposits for the Earthwatch roundhouse had not only some similarities to those of the Cookhouse but also

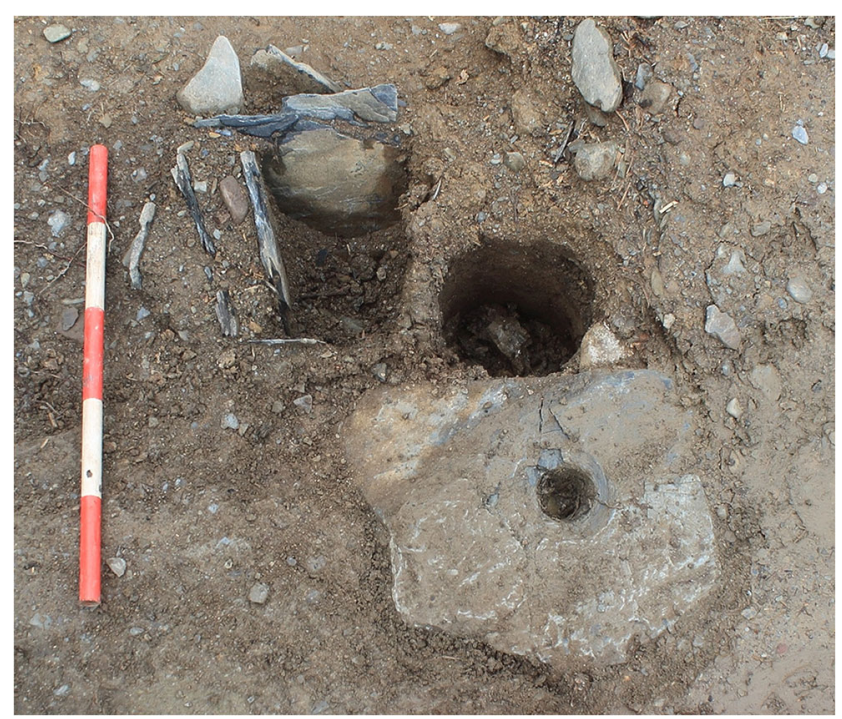

Fig. 26 Earthwatch roundhouse pivot stone for the door with postholes for replacement door jamb supports 


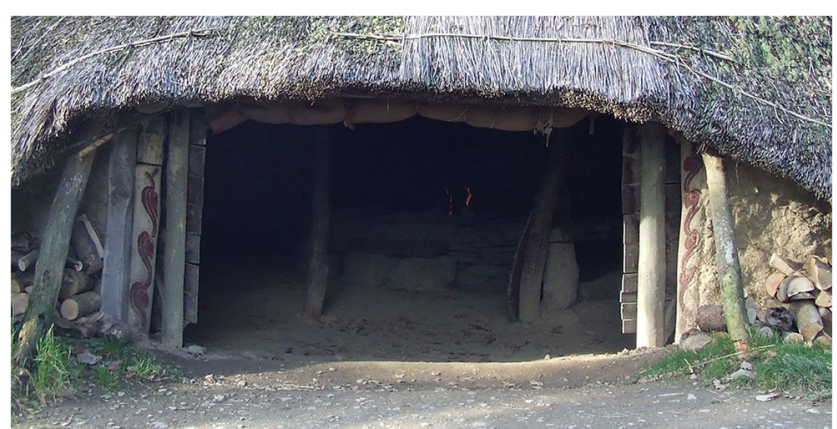

Fig. 27 Earthwatch roundhouse doorway modifications supporting the decorated original door jambs, taken 2017; note the naturally-formed eaves drip gully across the threshold

some notable differences. As a safety feature in this dark roundhouse interior used by schools' parties, the hearth was retained within a raised stone-walled structure after phase 1 , and though completely excavated and investigated, it is not discussed further here as it does not replicate any later prehistoric structure, beyond noting that it still created on the southern part of the interior charcoal-infused spreads of debris. Most activity during the 30-year use life of the roundhouse was concentrated round the hearth. This led to erosion of the upper slope on the northern side of the hearth (Fig. 23) and also at the entrance. Various attempts at patching, sometimes with clay, were noted and partially survived, but most notable were the successive raising of the floor levels in the southern half of the roundhouse in an attempt to make the interior floor closer to the horizontal.

The archaeological evidence for the roof props was visible in the upper floor surface as ghosts of where the posts had stood. These were not cut postholes but where the floor had been laid to a depth around in situ timbers (Fig. 23). At a lower level in the floor dumping, and indeed across the whole of the interior in a ring around the hearth, were the flat shale slabs on which these rafter props were placed in phase 2 (Fig. 21). Thus, the presence of the interior props are well attested archaeologically in this excavation, but if only even slightly truncated subsurface features survived, as is normally the situation on prehistoric excavations, these structural features would have left no trace. Not of structural significance but indicative of site management practices, mounds of interior sweepings accumulated against the wall of the roundhouse immediately to the north and south of the door jambs (Fig. 23). Across all of the interior floor surfaces, small artefacts such as sweet wrappers and ring pulls were trampled into the floor surfaces, and against the wall in the southern darkest, arc of the wall the raising of the floor levels meant that substantial amounts of refuse, not noticed in the dark periphery in what otherwise looked like a well-maintained roundhouse, were sealed and preserved.

It is notable that with both roundhouses, where the eaves extend close to the ground no gully naturally forms, and instead, there is a relatively dense growth of vegetation. In contrast, immediately beyond the eaves, there is wear through footfall, exposing the soil surface and leading to erosion. This is most notable on the southern exterior where the natural slope of the ground away from the wall was further emphasised by erosion due to passage of human feet over the decades and is most prominent in phase 3 (Fig. 23).

The Earthwatch roundhouse is now being reconstructed with most of the original design features retained, but with an internal ring beam. It is anticipated that this will secure the structural integrity of the roof and will not require any internal props. How the problems of the natural slope and effective use of the internal space will be most effectively resolved is still under consideration.

\section{Discussion}

The excavations revealed several archaeological signatures of relevance to those excavating prehistoric sites and also issues that are relevant for those planning experimental reconstructions. These can each be set out as a series of key findings.

\section{Experimental roundhouse reconstruction}

\section{Earthfast timbers-for construction or long-term stability?}

Bennett notes that the timber uprights for the inner ring of the Cookhouse roundhouse were already completely rotted at ground level after a decade (Bennett 2010). This is not dissimilar to the findings of Reynolds at Pimperne (Reynolds 1993, 93-113). The National Park determined that these posts, along with some of the wall and the door posts, which at that stage still had their hardwood centres intact, should all be replaced. Reynolds, in contrast, argues that rotted-off uprights could be kept in positon and the problem of any voids beneath them solved by infilling and the use of a stone pad edged in under the upright. The Earthwatch roundhouse had no interventions on the wall in its 30-year life, and did not have an earth-fast inner ring, though the National Park did add uprights to prop the rafters that were just set on small shale slabs on the floor, and which gave the impression of shallow postholes when the floor was raised around them. Set on the slabs, these did not rot off at the base and lasted intact for over 15 years. The inner ring of posts in the Cookhouse was replaced and then had rotted off again by the time of demolition. These still were effective in holding the roof up, but if their fixing in the roof led them to be loosely fixed on the ground, it would be easy to place a shale stone slab under the timber and so not only hold it in place but would also prevent further rotting by removing damp entering the timber. It should be therefore remembered that many ad hoc repairs and structural supports 
could be added within roundhouses, but they leave no subsurface traces and so will rarely be evidenced in modern excavations of later prehistoric sites.

Reynolds (1994, 1995) argues that the earth-fast nature of many of the timbers is only necessary at the construction phase when the integrity of the wattle and daub wall and the roof framework of rafters and purlins are not in place. The original wall posts of the Cookhouse roundhouse and those within the Earthwatch provide independent data which supports with this interpretation; the later changes to the Cookhouse roundhouse (including wall posts of excessive depth in large postholes packed with considerable amounts of stone and rammed clay, completely unlike any ancient example of the site) were not only inappropriate but also ineffective, with some of the replacement posts also rotted off at ground level by the time of demolition, and the others well advanced in decay from the outer surface towards the centre of the heartwood.

The main purpose of earth-fast posts - and therefore the archaeological signature of postholes - is and probably was in the Iron Age to provide stability during construction. This suggests that if some alternative strategy for holding uprights in place until the structural integrity was obtained then the subsurface archaeological signature of roundhouses could be very slight. The possibility of prefabricated production of construction elements with appropriate carpentry joints which could be rapidly slotted together whilst the uprights were held in place by the construction team should not be dismissed. This would be a hypothesis which could be tested in a future experiment.

\section{Artefact deposition}

A significant location of deposition related to the structural decay of the earth-fast timbers was described above. The buried timbers rotted to form a loose, friable material which attracted small burying mammals. The deposits were often clearly disturbed, and a number had artefacts such as paper and string carried down into the burrows. The animal burrows also extended into the material around the packing stones and so affected deposits that would on excavation be considered associated with the building's construction. It would also have been possible for small items to fall down the burrows and enter the below-ground deposits. This indicates that archaeologists should be extremely careful in assigning artefacts to either construction or destruction of a timber building, as they could have been incorporated at any time also during the duration of use and not through direct human action.

The main focus of this paper is to consider the structural evidence for the reconstruction compared with ancient excavated structures and the ways in which deposits formed during the use-life of the structure. However, it is worth noting that artefacts were incorporated into the deposits in both roundhouses, though detailed analysis of these will be published elsewhere (Mytum and Meek forthcoming). Tools used in maintaining the houses, and props associated with schools' activities including face painting materials, were kept in some of the darker spaces within the roundhouses and in some cases mislaid there. Some of these were recovered during the excavationmost notably several tins and lids of face paint from the Cookhouse, where illicit drinking was indicated by a few beer bottle caps tossed against the wall, though who was responsible for these is not known. Visitors are represented by a lost mobile phone battery, some coins and a significant number of sweet wrappers - reflecting the number of children visiting the site; these came from both inside the houses and outside-wind-blown under the eaves. Most finds did not come from the swept, maintained areas of the roundhouse at the entrances and around the hearths, but the darker edges; this selectivity in deposition is best represented by the cache in the Cookhouse of a metal bowl and tin of beeswax found under where the bed with a mattress raised up on legs was located and with accumulations of items against the wall sealed by the raised floor levels in the Earthwatch roundhouse.

\section{Roundhouse abandonment signatures}

The partial abandonment of the Cookhouse roundhouse prior to excavation, but after the roof was removed, gives indications of the archaeological signature of an abandoned roundhouse with this form of construction. This is a distinctive pattern of an annular ring of material which would rapidly attract vegetation cover, a ring that would partially seal the internal floor and the external build-up of deposits close to the original wall line. As the uprights had rotted off at ground level, when they fell over, they did not affect the integrity of the postholes, which were already largely filled with humic material. The fallen timbers could decay without significant archaeological trace, or they could be removed for reuse as slightly shorter timbers. If the roof had been left in place, the whole process would have been much slower, and the whole of the roundhouse plan - and its immediate area - would have been covered with a $0.25-\mathrm{m}$-thick layer of thatch and the gradually collapsing roof, creating a circular humic deposit which would protect the entirety of the floor area. The very dry weather (the driest in the UK for over 40 years) between dismantling and excavation for the Earthwatch roundhouse meant that these processes were not in operation during the observation period, but they would have commenced as soon as rain fell. Interior features such as clay hearths and ovens would collapse with rain and frost and form patches of broken and variably fired clay fragments. 


\section{Conclusions}

Long-term reconstruction experiments may be unable to maintain close monitoring of all variables that may affect structures, but they have the major advantage of providing access to the effects of processes of weathering and use that cannot be simulated in the short term. Each of the Castell Henllys timber roundhouses stood for at least 30 years and demonstrated that the hypothesised reconstructions could withstand a wide variety of climatic conditions and be maintained and used throughout this period. Dismantling and rebuilding were only necessary because of twenty-first-century health and safety concerns rather than what would probably have been late prehistoric acceptances of risk. The detailed evidence collected during building survey and excavation revealed that whilst 30-year lives may be a minimum for this type of structure, they could probably be maintained almost indefinitely if during rethatching, when much of the weight is removed from the building and all structural wall and roof timbers are accessible, necessary maintenance and replacement takes place. As with all reconstruction tests, these successful buildings do not prove that this is how they were actually built, used and maintained in the past, but they demonstrate how the experimental practices using technologies available at that time can produce viable regimes which leave archaeological signatures that are compatible with those found in excavation of later prehistoric settlements. The evidence from the experiments also highlights aspects of deposit formation and artefact patterning that requires sensitive interpretation, and they challenge some assumptions often made by excavators.

Acknowledgements The authors acknowledge the Pembrokeshire Coast National Park and the full co-operation of their staff at Castell Henllys in all aspects of the planning and implementation of the fieldwork. In particular, Delun Gibby and Liz Moore provided details of past and current practices concerning the buildings and much encouragement for our endeavours. Mytum has studied the reconstructions regularly over their use lives; both authors directed the two excavations, Meek created the excavation archives. Mytum wrote the text and selected the images, with Meek's agreement regarding content. Dr. Rob Philpott has produced the published versions of the line drawings, and Martha Crocker, Ellis Cuffe and Anna Fairley assisted with compiling the finds photographic archive. Professor Martin Bell kindly provided details of his work at St Fagan's. The fieldwork team consisted of local community volunteers and students from the University of Liverpool and other institutions; their dedicated efforts ensured both seasons of fieldwork were pleasant and productive.

Funding information The authors received funding for the fieldwork from the Pembrokeshire Coast National Park. The University of Liverpool provided some funding towards the postexcavation work, and the facilities in which it could take place.

Open Access This article is licensed under a Creative Commons Attribution 4.0 International License, which permits use, sharing, adaptation, distribution and reproduction in any medium or format, as long as you give appropriate credit to the original author(s) and the source, provide a link to the Creative Commons licence, and indicate if changes were made. The images or other third party material in this article are included in the article's Creative Commons licence, unless indicated otherwise in a credit line to the material. If material is not included in the article's Creative Commons licence and your intended use is not permitted by statutory regulation or exceeds the permitted use, you will need to obtain permission directly from the copyright holder. To view a copy of this licence, visit http://creativecommons.org/licenses/by/4.0/.

\section{References}

Banerjea RY, Bell M, Matthews W, Brown A (2015) Applications of micromorphology to understanding activity areas and site formation processes in experimental hut floors. Archaeol Anthropol Sci 7:89112. https://doi.org/10.1007/s12520-013-0160-5

Bell M (2009) Experimental archaeology: changing science agendas and perceptual perspectives. In: Allen MJ, Sharples N, O'Connor T (eds) Land and people: papers in memory of John G Evans. Oxford, Oxbow, pp 31-45

Bell M (2014) Experimental archaeology at the crossroads: a contribution to interpretation or evidence of 'xeroxing'? In: Chapman R, Wylie A (eds) Material evidence: learning from archaeological practice. Routledge, London, pp 62-78

Bennett $P$ (2004) Roundhouses in the landscape. Interpreting the Iron age at Castell Henllys. In: Frodsham P (ed) Interpreting the ambiguous. Archaeology and interpretation in early 21st century Britain. British Archaeological Reports, London 362, pp 83-88

Bennett P (2010) Castell Henllys: reconstruction and interpretation at an Iron Age fort. Archaeol J 167(supplement):23-27

Burrow S (2015) From Celtic Village to Iron Age farmstead: lessons learnt from twenty years of building, maintaining and presenting Iron Age roundhouses at St Fagans National History Museum. EXARC Open Archaeology 15:4. EXARC, Leiden. http:// openarchaeology.info/issue-2015-4/aoam/celtic-village-iron-agefarmstead-lessons-learnt-twenty-years-building-maintaining-andpresenting

Carey CJ, Wickstead HJ, Juleff G, Anderson JC, Barber MJ (2014) Geochemical survey and metalworking: analysis of chemical residues derived from experimental non-ferrous metallurgical processes in a reconstructed roundhouse. J Archaeol Sci 49:383-397. https:// doi.org/10.1016/j.jas.2014.05.017

Collings, M (2007) Roundhouse stories: reconstruction and public perceptions of the Iron Age. In: Grabow, S, Hull, D, Waterton, E (eds.) Which past, whose future?: treatments of the past at the start of the 21st century: an international perspective: Proceedings of a conference held at the University of York, 20-21 May 2005. Brit. Archaeol. Rep. Int. Ser. 1633. Oxford: Archaeopress

Crothers ME (2016) Experimental archaeology within the heritage industry: publicity and the public at West Stow Anglo-Saxon village. In: Hurcombe L, Cunningham P (eds) The life cycle of structures in experimental archaeology: an object biography approach. Sidestone Press, Leiden, pp 37-46

Cunliffe BW (1978) Iron age communities in Britain: an account of England, Scotland and Wales from the seventh century BC until the Roman conquest. 2nd edn. Routledge, London

Davies JR, Waters RA, Wilby PR, Williams M, Wilson D (2004) Geology of the Cardigan and Dinas Island district: a brief explanation of the geological map. British Geological Survey, Nottingham

Gruffudd RP, Herbert DT, Piccini A (1998) Learning to think the past: heritage, identity and state education in Wales. Int J Herit Stud 4(34): $154-167$

Gruffudd P, Herbert DT, Piccini A (1999) Good to think': social constructions of Celtic heritage in Wales. Environment and Planning D: Society and Space 17:705-721 
Guilbert G (1981) Double-ring roundhouses, probable and possible, in prehistoric Britain. Proc Prehist Soc 47:299-317. https://doi.org/10. 1017/S0079497X00008963

Guilbert GC (1982) Post-ring symmetry in roundhouses at Moel y Gaer and some other sites in prehistoric Britain. In: Drury PJ (ed) Structural reconstruction: approaches to the interpretation of excavated remains of buildings. British Archaeological Reports, Oxford

Harding DW (2009) The Iron age round-house: later prehistoric building in Britain and beyond. Oxford University Press, Oxford

Harding DW, Blake IM, Reynolds PJ (1993) An Iron age settlement in Dorset: excavation and reconstruction. Edinburgh University Press, Edinburgh

Hurcombe L, Cunningham P (eds) (2016) The life cycle of structures in experimental archaeology: an object biography approach. Sidestone Press, Leiden

Longley, D (1998) Bryn Eryr: an enclosed settlement of the Iron age on Anglesey. In Proceedings of the Prehistoric Society 64: 225-273. https://doi.org/10.1017/S0079497X00002231

Macphail RI, Cruise GM, Allen MJ, Linderholm J, Reynolds P (2004) Archaeological soil and pollen analysis of experimental floor deposits; with special reference to Butser ancient farm, Hampshire, UK. J Archaeol Sci 31:175-191. https://doi.org/10.1016/j.jas.2003. 07.005

Millson DCE (ed) (2011) Experimentation and interpretation: the use of experimental archaeology in the study of the past. Oxbow Books, Oxford

Mytum H (1986) The reconstruction of an Iron age roundhouse at Castell Henllys. Dyfed Bull Board Celtic Studs 33:283-290

Mytum H (1999) Pembrokeshire's pasts. Natives, invaders and Welsh archaeology: the Castell Henllys experience. In: Stone PG, Planel $\mathrm{P}$ (eds) The constructed past. Experimental archaeology, education and the public. Routledge, London, pp 181-193

Mytum H (2000) Archaeology and history for Welsh primary classes. Antiquity 74:165-171

Mytum H (2003) Evoking time and place in reconstruction and display: the case of Celtic identity and Iron Age art. In: Jameson JH Jr, Ehrenhard JE, Finn CA (eds) Ancient muses. Archaeology and the arts. University of Alabama Press, Tuscaloosa, pp 92-108

Mytum H (2004) Policy and purpose in reconstruction at Castell Henllys Iron Age fort, Wales. In: Jameson J Jr (ed) The reconstructed past. Reconstructions in the public interpretation of archaeology and history. AltaMira Press, Walnut Creek, pp 91-102
Mytum H (2012) Rebuilding the past: challenges in education and public interpretation at Castell Henllys Iron age fort. Arqueo Mediterrània $13: 73-81$

Mytum H (2013) Monumentality in late prehistory: building and rebuilding Castell Henllys Hillfort. Springer, New York

Mytum H, Meek J (2019) What goes around comes around: an Iron age roundhouse at Castell Henllys. Br Archaeol 2019:36-41

Mytum H, Meek, J (forthcoming) The iron age in the plastic age: Anthropocene signatures at Castell Henllys, west Wales

Piccini A (1999) Welsh Celts or Celtic Wales? The production and consumption of a (not so) different Iron Age. In: Bevan B (ed) Northern exposure. Leicester University Press, Leicester, pp 51-63

Planel P, Stone PG (eds) (1999) The constructed past: experimental archaeology, education and the public. Routledge, London

Reynolds PJ (1979) Iron Age farm: the Butser experiment. British Museum, London

Reynolds PJ (1982) Substructure to superstructure. In: Drury PJ (ed) Structural reconstruction, British archaeological report British series, vol 110, pp 173-198

Reynolds, P (1993) Experimental reconstruction. In: D W Harding, I M Blake, P J Reynolds, An Iron Age settlement in Dorset: excavation and reconstruction. Edinburgh, Edinburgh University Press, pp: 93 113

Reynolds, P J (1994) Experimental archaeology. A perspective for the future. The Reuvens Lecture 5, Stichting voor de Nederlandse Archeologie: 11-25

Reynolds P (1995) The life and death of a post-hole. Paper given to interpreting stratigraphy conference 5th May 1995 . Reproduced in Butser Ancient Farm Occasional Papers 1:27-32

Reynolds PJ (1999) The nature of experiment in archaeology. In: Harding $\mathrm{AF}$ (ed) Experiment and design: archaeological studies in honour of John Coles. Oxbow Books, Oxford, pp 156-162

Townend, S (2002) Interpreting people interpreting things: a Heideggerian approach to 'experimental reconstruction'. Papers from the Institute of Archaeology, 13:72-93

Townend S (2007) What have reconstructed roundhouses ever done for us? Proc Prehist Soc 73:97-111. https://doi.org/10.1017/ S0079497X00027316

Woltz C (2010) Ruin and reconstruction: understanding the constructed past. Muséologies 4(2):112-131. https://doi.org/10.7202/1033542ar

Publisher's note Springer Nature remains neutral with regard to jurisdictional claims in published maps and institutional affiliations. 